Portland State University

PDXScholar

\title{
A Descriptive Study of Participants in the Evergreen Community Organization
}

\author{
Douglas Edward Lehrman \\ Portland State University \\ Janet R. Abrams \\ Portland State University
}

Follow this and additional works at: https://pdxscholar.library.pdx.edu/open_access_etds

Part of the Behavioral Economics Commons, Education Economics Commons, and the Growth and Development Commons

Let us know how access to this document benefits you.

\section{Recommended Citation}

Lehrman, Douglas Edward and Abrams, Janet R., "A Descriptive Study of Participants in the Evergreen Community Organization" (1976). Dissertations and Theses. Paper 2120.

https://doi.org/10.15760/etd.2118

This Thesis is brought to you for free and open access. It has been accepted for inclusion in Dissertations and Theses by an authorized administrator of PDXScholar. Please contact us if we can make this document more accessible: pdxscholar@pdx.edu. 
A DESCRIPTIVE S'JUIDY OF PARIICIPANTS IN THE EVERGREFN COMMUNITY ORGANIZATION

\author{
by \\ DOUGLAS EDWARD LEHRMAN \\ and \\ JANET R. ABRAMS
} A practicum submitted in partial fulfiliment of the
requirements for the degree of

MASTER OF SOCIAL WORK

Portland State University.

1976 
TO THE OFPICE OF GRADUATE STUDIES AND RESEARCH:

The members of the Committee approve the practicum of Douglas Edward Lehrman and Janet R. Abrams.

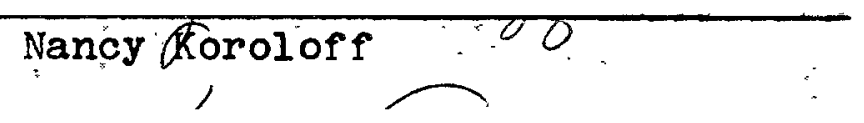
Kay Tofan 


\section{ACKNOWLEDGEMENTS}

The authors would like to thank the members of ECO who so graciously allowed their group to be the subject of this study. Their cooperation both as a group and individually was of great assistance in the completion of this project.

A special thanks also is extended to the consultants from the Unirersity of Washington Community Development team who gave the researchers access to study the group which the team was helping form. They also provided information concerning various phases of community development and were generally supportive of the project.

Acknowledgements could be made to numerous community leaders who assisted in various ways, but it is hoped that this general word of appreciation will substitute for trying to individually name each one. While the assistance and cooperation of all concerned is truly appreciated, the authors take full responsibility for the contents of this study. 
TABLE OF CONTENTS

PAGE

ACKNOWLEDGEMENTS . . . . ........... 111

LIST OF TABLES . . . . . . . . . . . . . . v

CHAPTER

I INTRODUCTION •. •. . . . . . . . . 1

II REVIEW OF THE LITERATURE ........ 11

Soclal Background-Demographic

Factors . . . . . . . . 17

Attitudinal and Motivational Dynamics

of Participation in Voluntary

Associations ........ 35

Summary of Literature Review . . . . 47

III METHODOLOGY ................ 49

IV RESULTS ................ 58

$\mathrm{V}$ AMPLIRICATIONS AND INTERPRETATIONS • • • • 93

VI SUMMARY AND RECOMMENDATIONS . . . . . 126

SELECTEN BIBLIOGRAPHY . . . . . . . . . . 136 APPENDIX I . . . . . . . . . . . . . 144 APPENDIX II . . . . . . . . . . . . . . 159 APPENDIX III . . . . . . . . . . . . 160 
LIST OF TABLES

TABLE

PAGE

I Age of "Active" ECO Members . . . . . . 58

I Number of Children "Active" ECO Members

Have . . . . . . . . . . . .

II Ages of Chilaren of "Active" ECO

Members . . . . . . . . . . . . .

IV Public School Attendance of "Active"

ECO Members' Chilaren ..........

$\mathrm{V}$ Total Family Income of "Active"

ECO Members . . . . . . . . . . .

VI Educational Level of "Active" ECO

Members And Their Spouses . . . . .

VII Type of Work of "Active" ECO Members

And Their Spouses . . . . . . . . .

VIII Elementary School Areas In Which

"Active" ECO Members Reside And

These Areas' Participation In Free

And Beduced Price Hot Lunches In

1974-75. . . . . . . . . . . .

IX Religlous Preference of "Activé" ECO

Members . . . . . . . . . . . .

$X$ Political Activity of "Active" ECO

Members . . . . . . . . . . . . 
XI Number And Types of Candidates "Active" ECO Nembers Campaigned For In The Last 4 Years . . . . . . . . .

XII Types And Number of Public Meetings

Attended In The Past Year By "Active"

ECO Members . . . . . . . . .

XIII Membership In Community Or Service

Organizations of "Active" ECO Members

And Their Spouses .. . . . . . .

XIV "Active" ECO Members' Perceptions of

Co-workers' Views About Those Members'

Participation In ECO . . . . . .

XV "Active" ECO Members' Views Concerning

The Perceptions of "Local" Government

Officials About ECO . . . . . . .

XVI Family Attitudes Towards "Active" ECO

Member's Participation ........

XVII "Active" ECO Members' Friendship

Relations Relative TO ECO ......

XVIII Length of Residence In Current Home

Of "Active" ECO Members . . . . .

XIX Length of Residence In The Evergreen

Area of "Active" ECO Members ......

$X X$ Place of Employment of "Active" ECO

Members And Their Spouses 
XXI Participation of "Active" ECO Members In ECO ............... 80

XXII Length of Community Activity of.

"Active" ECO Members . . . . . . . . 81

XXIII Decisions To Participate And Do So On

An Active Basis Made By "Active"

ECO Members . . . . . . . . . . .

XXIV What "Active" ECO Members Hoped To Learn

By Participating in ECO .........

XXV "Active" ECO Members' Perceptions of

Co-workers Views of Those Members

Participation In ECO.......... 84

XXVI "Active" ECO Members' Perceptions of

The Decision Making Process Occurring

In ECO . . . . . . . . . . . 85

XXVII "Active" ECO Members' Views of The

University of Washington Consultants'

Activities . . . . . . . . . . 86

XXVIII "Active" ECO Member's Degree of Concern

With Community Problems ........

XXIX Relative Importance of Community Issues

As Perceived By "Active" ECO

Members . . . . . . . . . . . . .

XXX Evergreen's "Main Problem" As Identified

By "Active" ECO Members . . . . . . 90 
vili

TABLE

PAGE

XXXI "Active" ECO Members" Prioritizing

Of Projects Which They Would

Like ECO To Undertake . . . . . . . 91 


\section{CHAPTER I}

\section{INTRODUCTION}

The purpose of this study is to present a descriptive analysis of the active participants in a voluntary association concerned with communtty development. This analysis will focus upon description and discussion of the sociodemographic characteristics of the active members of the organization. Some of the attitudinal factors whioh operated to motivate and sustain participation in the organization will also be examined. Before proceeding with discussion of the theoretical background for the study, the community and its history relative to development of the organization will be described.

Evergreen is an unincorporated area lying oast and north of Vancouver, Washington, in Clark County, which is presently the fastest growing county in the state of Washington. The Evergreen area has absorbed much of Clark County's growth within the past ten to fifteen years, and has been in a process of rapid transition from rural agricultural area to suburban residential development area, with corresponding increases in both absolute population size and population density. Evergreen is now primarily a residential area--most of its residents work in Vancouver, elsewhere in Clark County, or in Portland, Oregon, just across 
the Columbia River. Industrial development has not materialized in Evergreen; the agricultural base is shrinking as the population rises and more land is given over to residential development. The result of these processes is that Evergreen's largest economic concern and employer is its school system.

Not only is the Evergreen School District the largest single economic concern within the area, it is Evergreen's only defining characteristic as a community and is often identified as the community's most pressing problem area. In order to present a picture of Evergreen, it is necessary to discuss how schools are financed in washington, how problems of school financing are the central core of Evergreen's community concerns, and how these problems are related to Evergreen's economic structure as well as its rapidly increasing population in recent years.

Evergreen, like other school districts in the state. must rely primarily upon property taxes as its sources of operating revenue. This structure necessitates heavy reliance upon annual operating appropriations determined by budget recommendations made by the $8 \mathrm{chool}$ board and administration and submitted to local voters in an annual levy election. This method of school financing has become a major political issue in Washington in recent years, with pressure for reform of the state's taxation structure as it relates to school support being at the core of the issue. 
Those who seek a change in the present system of school financing, would like to see the state assume increased responsibility for school funding with funding to be shifted from the local to the state level. The hope among the reformers is that this shift would work to equalize the amount avallable to finance schools throughout the state, eliminating disparities in revenue avallable for education from district to district. The propositions for reform have generally included proposals for new forms of statewide taxation, including imposition of a state income tax, which Washington presently does not have. The income tax 1ssue is an inflammatory one in Washington, and several proposals have been defeated by Washington voters in the past few years. The result of these political processes has been to maintain the annual property tax levy election as the major source of school operating funds. In Washington, a school levy measure may be submitted to district voters a maximum of two times each year.

Th1s form of school funding affects Evergreen and other rapidly growing suburban districts in a unique way. Since Evergreen is primarily a residential district, with some agricultural property and almost no industrial development, it must rely upon residential property for its tax base. Since the assessed valuation of residential property is lower than that of industrial property, Evergreen has a relatively low property tax base upon which to levy property tax 
appropriations, which results in the necessity to levy more dollars of tax per unit of assessed property value in order to raise a given amount of revenue. The consequence of this condition in Evergreen has been increased resistance to property tax levy requests and the resulting defeat of the spectal school levies in 1974 and 1975.

The defeat of these levies has contributed to increasing problems within the Evergreen School District. As the population has continued to grow and the amount of dollars avaliable for schools has decreased through levy defeats, the schools have become overcrowded, the teachen-pupil ratio has increased, and the educational program has suffered as 1 ess money is avallable to hire teachers, buy books and supplies, run school buses, provide school lunches, and support all of the elements of a comprehensive educational program. For example, the district was forced to close four of 1 ts twelve elementary schools in 1975-76, to move 9th grade from the junior high schools to the high school, and to make numerous cuts in personnel and program budgets following the defeat of the 1975 speciel operating levy at the polls.

Given these conditions and their dynamics inherent in state and local politics, Evergreen's citizens have begun to take some action to deal with the concerns of their area. Most of these concerns have their roots in the school dilemma and in the interrelated problems of growth that Evergreen has experienced in the past few years. The Evergreen community 
Organization (hereafter known as ECO), is one of the organizations that has been formed to address the problems of Evergreen, and it is useful to trace its derelopment to the point where the present research about the particlpants begins.

In the Fall of 1973, a new superintendent was hired by the Evergreen School District. As part of his approach to dealing with the problems relating to school finanolng in Evergreen, he developed programs that were designed to encourage total community support for schools on a regular basis. Part of this effort included appointment of a levy chairperson who was charged with mobilizing support for school financing on year round basis, as an alternative to the short-term levy campaign which is held annually. Following the defeat of the 1974 levy in the spring of that year, the first ongoing levy chairperson was appointed.

In doreloping a more concerted, grassroots approech to citizen involrement in the schools, the levy chairperson met informally with a group of citizens to discuss oommon concerns. As their discussions progressed, it became increasingly apparent that the problems of school financing in Evergreen were interrelated with a number of other community concerns stemming from rapid growth in the district. This group (calling itself Citizens United for Evergreen, hereafter knom as CUE) continued to moet and discuss $18 s u e s$ and possible solutions throughout the remainder of 1974; their 
discussions included debate about the desirability of forming a citizen's organization to take action on community problems. After deciding that such an organization was indeed desirable, and after much discussion of the form that the organization should take (including discussion of by-laws and other structural 1ssues), a formal charter was approved by the group in the late Fall of 1974.

As CUE members discussed Evergreen's problems and possible solutions through the Pall and winter of 1974-75, it became increasingly apparent to them that some form of community development program for Evergreen was desirable, given the intensity of the problems faced, the lack of an established community base, and the perceived lack of communtty spirit and identity. It was at this time that some CUE members learned about the community development program sponsored by the Community Development Division of the University of Washington in Seattle. Consultants from the Division were invited to Evergreen in February of 1975, and the program of consultation which lead to development of the Evergreen Community Organization (ECO) was begun, with CUE being the sponsoring organization for the development of ECO. A significant number of persons hold memberships and are active in both organizations.

The first community meeting with the University of Washington consultants took place in late February, 1975 , with about 100 persons present. At this meeting, the 
consultants explained the community development program, which is organized into three phases, including: (1) Surrey-a including derelopment of a questionnaire about issues which nes to be administered to every household in the district, (2) Study of the results of the survey and the comminity issues raised by the survey, and (3) Action on the priority issues as developed by the surrey and study phases. As outlined by consultants, the program necessitates involvement by as many citizens as possible throughout all three phases. The persons present at the first meeting wero organized into three committees, including: (1) Questionnaire Committee (charged with developing the survey instrument), (2) Boundary Committee (charged with determining the boundaries of the areas to be surveyed and with recruitment of interviewers for the surrey), and (3) Communications Committee (charged with publicity about organization activities).

The committees began work immediately; officers and a name for the organization were selected at the next general meeting. Through the Spring of 1975, the questionnal re committee worked to develop a surrey instmument th a tentative date for the community-wide survey set for early June. It became apparent in late May that this deadilne was not realistic for several reasons: (1) The questionnaire was not as complete or well written as 1 t might hare been; (2) The Division of Community Development was running out of money In its fiscal year budget, and would not be refunded until 
July 1. Therefore, the Division was unable to send the consultants to Vancouver for a period of several weeks through May and June, and the same budget problems made it impossible to print the questionnalre until after July 1; (3) The organization determined that summer was not a good tjme for a survey due to people being on vacation and difficulty in recruiting interviewers. For these reasons, it was decided to delay the survey until Pall. The organization therefore changed focus through the summer, devoting itself to raising funds through a variety of projects. These projects included sponsorship of a rock concert for youth, a baked goods sale, and a game booth at the community fair. It should be noted that participation in the organization had dropped through the Spring from the original 80 to 100 persons to an active core of about 20 to 25 persons by the beginninf, of summer.

The questionnaire committee finished drafting the survey over the summer and 1 t was sent to seattle for a critique by members of the Division staff. The revised instrument was presented to a general meeting of ECO in midSeotember, and training sessions for the interviewers took place in late september. About 100 interviewers had been recruited, instead of the originally projected 600 , so the size of the survey area was correspondingly reduced and not every household in the district was surveyed. It should be noted that the survey sample was not drawn scientifically, 
so from a pure research perspective, the survey results may be open to various questions of validity. However, the primary purpose of the survey was to generate community involvement and discussion of the issues, rather than the collection of data that is methodologically sound in all respects: The survey was done in early october, and results were sent to seattle to be tabulated. In early December 1975 , the completed survey results were presented to an ECO meeting, and the survey phase of the community development program was completed.

The authors participated as members of ECO throughout its rormation and are residents of the Evergreen area. It was decided in early April to proceed with a study of active participants in the organization with a view to describing their social/demographic characteristics and their attitudes relevant to participation in ECO and in community affairs in general. After consultation with the University of Washington community development consultants, with community leaders, and with faculty at Portland State University's School of Social Work and Department of Urban Studies, it was decided that the 11 terature on voluntary associations and participation was a relevant theoretical framework from which to proceed. The rationale for this study, therefore, was related to an interest in describing this group of voluntary association participants in terms of their demographic and social characteristics and their attitudes relevant to participation in 
this organization, given the fact that development of such an organization is a relatively recent phenomenon in the Evergreen area. 


\section{CHAPTER II}

\section{REVIEW OF THE LITERATURE}

In order to establish a theoretical framework for this study, a review of literature in the field of voluntary association was undertaken by the researchers. This reviow will present a conceptual overviow of two major components of analysis in the field of voluntary action research; namely, demographic and social characteristics of participants, and attitudinal characteristics related to participation in the voluntary activity under study. The focus of this review will be upon 11 terature that pertains to the development and concerns of the present study.

David Horton Smith (1972) presents the ides of a need for scholars of voluntary action to adopt conceptual frameworks that will link together the various studies in the field. Smith points out that rragmentation has occurred in the knowledge that does exist in the field, and that intensive work is necessary to synthesize the ideas and concepts that have been developed in the fleld of voluntary action. Smith presents a framework that he considers to be an inttial contribution to this effort at synthesis. He describes his efforts as follows:

This framework indicates the major substantive kinds of questions to which voluntary action research and theory are to be aninly directed 
These are the overall basic needs for research in roluntary action.. The scheme attempts to encompass all major relevant aspects of voluntary action. 1

Smith's argument is based upon his view of the prosent state of the literature in voluntary action research as being iragmented and chaotic. His work 18 an attempt to bring order to the "chaos" by developing a comprehensive system of analybis for the field.

Smith begins this effort by distinguishing five main types of voluntary action, each with corresponding types of individual volunteers.

(1) Service-oriented roluntarism is that form of voluntary action that is primarily dedicated to helping others or doing things for others (e.g. Red Cross, court volunteers, hospital volunteers, eto.)

(2) Issue-oriented or cause-oriented voluntarism is that form of roluntary action that is primarily directed at some kind of public issue, usually at making some kind of change in society or the biophysical environment.

(3) Consummatory or self-expressive voluntarism is that form of voluntary action that is primarily aimed at enjoyment of activities for their own sake and for the sake of personal self-expression and self-realization without any major focus on altruism or external goals (country clubs, bowling leagues, etc.)

(4) Occupational/Economic self-interest roluntarism is that form of voluntary action that 18 primarily aimed at furthering the occupational and/ or economic interests of its participants (trade unions, professional associations, businessmen's groups, etc.)

(5) Philanthrop1c/Funding voluntarism is that form of voluntarism that is primarily aimed at

1Smith, David Horton (1972a); pp. 10-11. 
raising and/or distributing funds to non-profit and voluntary organizations of all kinds in order to further philanthropic purposes in such areas as health, pelfare, education, religion, politics, environment, etc.1

In terms of Smith's typology of voluntarism, it is cloar that the object of the present study (ECO) fits with Smith's notion of "1ssue-oriented or cause-oriented voluntarism". BCO is clearly a social-change oriented voluntary adoociation, given Smith's delineation of characteristics of different forms of voluntarism.

Having outlined the major substantive types of voluntarism in terms of types of goals sought, Smith proceeds to note some of the various social structural forms of voluntarism, or what he terms "system levels" of voluntary action.

(a) The roluntary act is the most basic structural form, referring to some specific oot by an individual or group that qualified as voluntary action in terms of earlier definitions.

(b) The voluntary role at the next higher level, refers to a set of normative expectations regarding a series of primary voluntary acts to be performed by some individual or group.

(c) The informal voluntary group is a group that lacks a formal leadership struoture, a unique proper name, and clear group boundaries, but that has goals that primarily require its membors to perform voluntary roles and acts.

(d) The formal voluntary group is an organized group (having a formal leadership structure, a unique proper name, and clear group boundaries) that has goals primarily requiring its members to perform voluntary roles and acts, and possibly including within it one or more informal voluntary groups.

(e) The roluntary sector of society is the thole

1 Ibid., pp. 1-2 
complex of non-governmental, non-commerclal groups, organizations and roles within a given society that are almed at all kinds of substantive voluntary action goals.

(f) A voluntary society is a society that places a high level of reliance on voluntary action as an organizing principle for human behavior, with only a minimum dependence on coercion, compulsion, or remuneration as driving forces for individual or group activity. 1

In terms of Smith's typology of social structural forms of voluntarism, it is clear that the focus of analysis of the present study is upon type (d), the "formal voluntary group." ECO fits the criteria of formal leadership structure, unique proper name, and clear group boundaries, as well as possessIng organizational goals. It seems clear that, of the social structural forms of voluntarism delineated by Smith, it is this form that is being studied with regard to ECo. It is important to present another phase of Smith's analytic framework in order to give perspective to the study of participation in ECO. Smith presents a number of conceptual categories for research as a basic part of his efforts to synthesize the ideas and concepts of voluntary action. It is useful to present all of the categories in order to determine where the present study fits into Smith's framework. The elements are:

(a) Definitions, theory, and conceptual issues in voluntary action.

(b) Nature and development of voluntary action from early times to modern society.

(c) History of theory, concepts, and ideas of voluntary action and related topics.

(d) Nature and determinants of the incidence of growth, change, and cessation of voluntary activity

${ }^{1}$ Ib1d., p. 2. 
in territorially based systems.

(e) Nature and determinants of the incidence, growth, change, and dissolution of voluntary groups and organizations.

(f) Nature and determinants of relationships between voluntary groups and other groups and individual affiliates.

(g) Nature and determinants of the effectiveness of voluntary groups and their impact on sooial processes, social institutions, the larger society, and the bio-physical environment.

(h) Nature and determinants of the internal structure and functioning of roluntary groups, organizations, and related collectivities.

(1) Nature and determinants of individual voluntary activity and role selection.

(j) Nature and determinants of the impact of voluntary action upon individual participants.

(k) Nature and determinants of the impact of exceptional individuals upon and through voluntary action of various kinds.

(1) The values of voluntary action.

(m) The futures of voluntary action.

(n) Development of methods for studying voluntary action.

(o) Development of voluntary action theory and research as a professional and soholarly field of interdisciplinary study. 1

The researchers have presented this summary of Smith's theoretical framework for the study of voluntary action in: order to locate and provide perspective for this study within the broad field of voluntary action research and also in order to provide a focus for the study of specific aspects of the organization under investigation. It is important to view the racets of the organization which are under study in their relationship to other aspects of voluntary association research in order to help to maintain a focus of anelysis. Given Smith's typologies, it is apparent that the study will

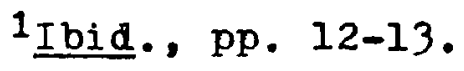


focus upon aspects of the nature and determinants of individual voluntary activity and of the impact upon individual participants (" $i$ " and " $j$ " in Smith's list of major analytical topics) in issue-oriented voluntarism ("2" of Smith's typology of main forms of voluntary action) in a formal voluntary group ("d" of Smith's typology of social structural forms of voluntarism). In other words, ECO is a formal voluntary organization with an orientation to issues (community planning and problem solving), and the focus of the study is upon a descriptive analysis of the participants in the organization in terms of social characteristics and attitudes toward participation in ECO.

Smith points out that the establishment of a conceptual framework is a necessary step in the development of voluntary action theory because of the diversity of disciplines involved in the fleld, the lack of intercommunication between scholars in these fields, and the "general lack of commitment of scholars in various disciplines and countries to the whole field of voluntary action research." 1 Furthermore, Smith sees need for synthesis and summary of the ideas and concepts of voluntary action as being of "prime importance both for the process of voluntary action research itself as a field of inquiry and also for the application of such scientific knowledge to on-going voluntary action." 2 He argues that such a

$$
\begin{aligned}
& 1_{\text {Ibid., p. }} 3 . \\
& \text { I Ibid., p. } 5 .
\end{aligned}
$$


process will facilitate the linkage of theory and practice in the field of voluntary action.

Smith's view of the necessity for organization of the research in voluntary action led to his 1972 book, ${ }^{1}$ a major work in the field that is directed toward summary and synthesis of the research on voluntary action. This book provided a valuable reference source in the development of the present research project, and the authors utilized Smith's framework extensively as a guide to further research in the areas under investigation. Given the perspective that the major foci of the present study lie in the areas of social characteristics and attitudinal dymmics of participants in ECO, it is possible to present the findings from the literature that the researchers found to be most relevant to the topic of this study.

\section{SOCIAL BACKGROUND-DEMOGRAPHIC FACTORS}

Payne, Payne, and Reddy, ${ }^{2}$ writing in Voluntary Action Research: 1972, postulate several clusters of social background ractors that are essential to the study of particiDation in voluntary organizations. An outline of these clusters follows.

${ }^{1}$ Sm1th (1972); Voluntary Action Research: 1972.

2 Payne, Payne, and Reddy; "Social Background and Role Determinants of Individual Participation in Organized Voluntary Action;" in Smith, Reddy, and Baldwin (eds.) Voluntary Action Research: 1.972 . 
(1) LIFE CYCLE STAGE
A. Age
B. Marital Status
C. Number of Children
D. Age of Children

(2) SOCIOECONOMIC STATUS
A. Income
B. Education
C. Occupational Status
D. Family or Lineage Status
E. Home Ownership

(3) SOCIO-PHYSICAL CHARACTERISTICS
A. Sex
B. Race
C. Ethnicity
D. Personal Health
E. Physical Abilities

(4) FORMAL ORGANIZATIONAL AFFILIATIONS AND ROLES
A. Occupation and Work
B. Religion
C. Politics
D. School Affiliation (if attending)

(5) INTERPERSONAL ROLES AND EXPERIBNCES

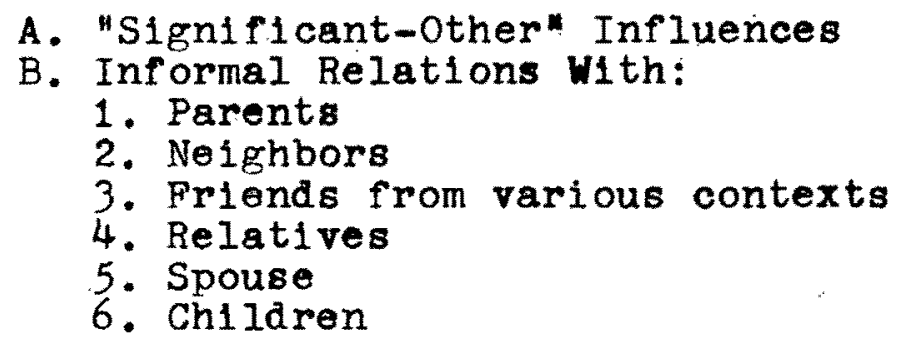

(6) RESIDENTIAL MOBILITY AND LENGTH OF TIME RESIDENT IN A GIVEN COMMUNITY

Payne et al. proceed to examine some literature which addresses the various issues studied by researchers in voluntary action. A summary of these studies, as well as some others found by the present researchers in thetr investigation of 
the literature, is presented here under the topics of social background factors as developed by Payne et al. and presented above.

\section{Life Cycle Stage}

Age: Payne et al. cite a study by Mayo (1950) which they consider to be the best study relating age and participation in voluntary associations. Mayo studied participation rates for each person over ten years of age in the farm families or a South Carolina county and noted an increase in participation from age 10-14 to age 15-19. However, Mayo and others, including Argyle (1959), Schuyler (1959), and Wilensky (1961), note a sharp decline in participation rate in the years between 20 and 30 , finding this age range to have the lowest rate of all age ranges studied.

From these lows, participation rebounds in the middle years of life, wth the peak levels generally occurring in the middle 40 's (plus or minus 10 years), with most researchers rinding membership and participation increasing throughout the middle years. A study which is representative of these age findings is that by Goldhamer (1942).

Marital Status: Marital Status has been examined as a factor in voluntary organization participation by sereral researchers. Almost without exception, these studies have shown that married persons have higher rates of both membership and participation in voluntary associations than those who are widowed, separated, or divorced. Representative 
studies showing this pattern are those by Goldhamer (1942), Hunter and Maurice (1953), Bell and Force (1956a), Scott (1957), Wright and Hyman (1958), Hausknecht (1962), Babchuk and Thompson (1962), Spiro (1968) and Booth and Babchuk (1969).

An interesting finding by Babchuk and Gordon (1962) indicates that a positive relationship exists between being unmarried and the assumption of leadership roles within voluntary organizations.

Number of Children: Number of Children of participants has been related to participation variables by a number of investigators, but the evidence regarding this variable is not entirely clear. In general, the more children a paront has, the more likely it is that he or she will join associations and participate in them. Several studies have found this generalization to hold, including those by Goldhamer (1942), Schmidt and Rohrer (1956), Scott (1957), Wright and Hyman (1958), Devereux (1960), Babchuk and Gordon (1962), and Spiro (1968). However, there are some studies that indicate that memberships may decline gradually when the number of children exceeds two, as found by scott (1957) and Lazerwitz (1962). Other research indicates no relationships between number of children a parent has and his or her participation in voluntary organizations, including studies by Lazerwitz (1961) and Babchuk (1965). It appears to be difficult to generalize from this often conflicting data, although the evidence seems to indicate that participation in voluntary 
organizations is most likely when a parent has one or two children.

Age of Children: Payne et al. point out that very little research has investigated the relationships between participation rates of parents and age of children. However, the studies which have examined this dimension of social characteristics of participants have indicated that having all children of school age favors higher membership and participation rates. This finding was borne out in studies by Schmidt and Rohrer (1956), Lazerwitz (1961), Spiro (1968), and Harry (1970). Harry (1970) and Schmidt and Rohrer (1956) also found that having preschool children has a greater influence on wives than on husbands, acting generally to reduce levels of associational involvement.

Payne et al. summarize this section by discussing life cycle stage as a complex of variables.

In general, membership and participation in voluntary associations . . are formally possible and begin after about age eight .. In adult directed and dominated groups . . . Although evidence 1. omewhat scanty, it seems that rates of membership and participation grow steadily from age eight until after graduation from high school or college... After individuals have left school, there appears to be a notable decline in individual membership and participation, especially for those who marry and are in the process of starting both their families and their occupational careers. Thus, during this period between age twenty and age thirty, membershtp and participation fall to a relatively low level. From this period on, married individuals tend to exhibit higher rates of involvement than the nonmarried. Having children and especially having children of school age seems to increase these rates of adult membership and participation. Rates of membership, participation, and leadership once more reach a peak in the middle years $(50-60)$ but begin 
to decline steadily and with generally increasing rapidity as age increases, as children reach the later stages of adolescence and young adulthood, and as retirement approaches and is reached. It would seem that the highest rates of instrumental voluntary action are especially likely to occur during this high participation ("middle-age") stage of the life cycle.

Finally, as membership, participation, and leadership rates in organized (and instrumental) voluntary action decline in later stages of the 11 fe cycle, religious and other expressive (and especially sociability) activities come to predominate. 1

\section{Socioeconomic Status}

The second major cluster of social background factors discussed and reviewed by Payne et al. With regard to influence on participation in voluntary associations is that of socioeconomic status, including the following variables.

Income: Payne et al. point out that the most salient generalization relating to this variable is that higher income is markedly associated with greater membership, participation, and leadership in voluntary associations. They cite a number of United States studies in which these findings hold consistently, including those by Mather (1941), Komarovsky (1946), Reid and Ehle (1950), Uzzell (1953), Reissman (1954), Axelrod (1956), Wright and Hyman (1958), Babchuk and Thompson (1962), Hodge and Treiman (1968), and others. Payne et al. summarize their findings on income and its relationship to voluntary association as follows.

In general, higher participation rates, in terms of both numbers of memberships and intensity of involvement, are found to be associated with higher

${ }^{1 \text { Ibid., p. } 214 .}$ 
income levels, particularly among persons with more education. However, there is some indlcation that participation rates may drop off somewhat at extremely high income levels.

Higher income is seen as the means with which persons oan afford membership fees and other costs of joining and participating. Even more significantly, higher income usualiy implies eligibility for a wider varlety of special and general interest groups, as well as being associated with higher educational and occupational status, which in turn tend to afrect participetion. An additional important relationship between income and participation in voluntary organizations suggested by these studies is that participation may itself directly or indirectly onhance income by providing contacts with potential customers, clients, and associates. Hence, there are some suggestions that higher income may be both (sic) a cause, a consequence, and a correlate of individual participation in organized voluntary action. There are no longitudinal studies we know of to settle this question. 1

Education: Payne et al. observe that the major generalization to be made concerning this variable is that "participation in voluntary formal organizations 18 strongly related to level of education, with higher levels of education being associated with both more extensive and intensive involvement." 2 This relationship has been reported in a wide range of samples in the United Stateg, including studies by Anderson (1938), Mather (1941), Goldhamer (1942), Komarovaky (1946), Freedman and Axelrod (1952), Wright and Hyman (1958), Zimmer and Hawley (1959), Hauskmecht (1962), Erbe (1964), Hagedorn and Labowitz (1967), Hodge and Troiman (1968), Spiro (1968), Hyman and Wright (1971), Smith (1972) and others.

$$
\begin{aligned}
& 1_{\text {Ib1d. }}, \text { p. } 215 . \\
& 2_{\text {Ib1d. }}
\end{aligned}
$$


Payne et al. state that major national surveys of voluntary associations membership in the United States (the American Institute of Public Opinion survey of 1954 and the National Opinion Research Center survey of 1955) have found that $75 \%$ of the respondents having college education had memberships in associations compared with $60 \%$ of those who had attended high school only, and about $40 \%$ of those with an elementary school education only. The foregoing results were reported by Hausknecht (1962). Payne et al. state that subsequent studies have found broadly simflar differences in participation by educational levels. D.H. Smith summarizes the explanations of these phenomena, confirming the hypothesis that more educated people participate more because of (a) greater access to voluntary associations at their higher socloeconomic levels, (b) greater ability to understand and be committed to abstract goals, (c) greater understanding of and familiarity with organizational operation, and (d) greater self-confidence, social confidence, etc. (Smith, D.H., 1972)

Finally, the authors discuss differences in the types of organizations to whioh people belong as a function of the extent of formal education. Studies by Hagedorn and Labovitz (1967), Scott (1957), and Axelrod (1956) have shown that "more educated people tend to participate more in profession-, al, business, civic, educational, scientific, cultural, social service, and political groups. Less educated persons tend to participate more in labor unions, sports and recreational groups, hobby clubs, fraternal lodges, and other kinds of 
groups with rather concrete and immediate goals, whether instrumental or consummatory."1 In terms of Smith's earlier typology of kinds of voluntary associations, it appears that people with more formal education tend to become involved in issue-oriented or cause-oriented voluntarism more than do persons with less formal education.

Occupational Status: With respect to this variable, Payne et al. found that "higher levels of occupational status have been found to be positively related to higher rates of membership and participation across the range of sample types from rural community studies to national sample surveys in the United States." 2 This generalization is upheld by evidence from studies by Anderson (1938), Chapin (1939), Warner and Lunt (1941), Goldhamer (1942), Komarovsky (1946), Reissman (1954), Foskett (1955), Nolan (1956), Scott (1957), Wright and Hyman (1958), Devereux (1960), Babchuk and Gordon (1962), Hausknecht (1962), Hagedorn and Labovitz (1967), Hodge and Treiman (1968), Spiro (1968), Hyman and Wright (1971), and Smith (1972), among others.

Other general findings reported by Payne et al. include the following: (1) Virtually all studies report that individuals in the lower socioeconomic groups tend to have few or no affiliations except religious affiliations. (2) The working class or blue collar worker is likely to belong to one or

$$
\begin{aligned}
& { }^{1} \text { Ibid., p. } 216 . \\
& { }^{2} \text { Ibid. }
\end{aligned}
$$


no more than two formal organizations. Evidence for this finding, comes from studies by Cousens (1964), Wright and Hyman (1958), Hausknecht (1964) and Lynd and Lynd (1929). (3) Working class individuals usually belong to different types of organizations than do members of the middle and upper classes. They are most likely to participate in those organizations that stress "practical and personal benefits, and direct action.. . in contrast to most formal organizations whose goals are abstract and intangible." 1 (4) Many working-class persons may have sufficient income and not have access to certain formal voluntary organizations nor interest in many that are open to them.

Cousens (1964) found that in the area he studied, only $17.5 \%$ of parents belonged to school-related organizations that were open to all parents. He found that parents who did not participate valued education and wanted good education for their children, but had no desire to participate in school clubs for the rollowing reasons:

(a) Because of their own limited education, these parents are unable to translate, without help, their concern, interest, and aspirations for their children into the type of abstract program and activity provided by the school clubs.

(b) Because of their limited exposure and experience with formal associations, they are reluctant or inadequate to assume the initiative in seoking out the club in order to become a member.

(c) Attendance at $\mathrm{school}$ meetings may be frustrating and unrewarding if the program is above their level of understanding or if they are not received with much warmth, interest, or cordiality at the school.

\section{${ }^{1}$ Ibid., p. 217.}


(d) The club leadership may be inadequate in meeting the needs of the membership through the activities which are sponsored. 1

Continuing with their discussion, Payne et al. point out several more dimensions of the issue of ocoupational status as it related to participation in voluntary assoolations. They note that: (5) The middle-class person is expected by society and by the nature of their occupational roles to have more memberships in voluntary organizations because such organizations provide occupational and professional development opportunities. (6) Also, sooloeconomic status (class) has been found to affect the social participation of the upper class professional and managerial couples, who most frequentiy approximate the popular notion of "togetherness" by their frequent joint participation in church and recreational organizations (Adams and Butlor, 1967). (7) One national study of urban married women found particlpation in voluntary associations to differ by socioeconomio class, with the definition of the role of wife being the significant variable. The working class wife was more likely to have a conflict between housework and active membership. In the upper middle class, the role of "wife" appears to be more compatible with voluntary group membership (Slater, 1960).

Furthermore, as Payne et al. observe: "organizational participation may be recognized by many as the means or rertical social mobility. At the same time, membermip in certain 
organizations may identify persons as belonging to given social classes, thereby serving a labeling or stereotyping function . . a given type of membership may be seen as an aspect of either achieved or ascribed status... "1 Finally, as Ross (1972) found, particlpation in formal voluntary organizations or community groups may be required as company policy, or as a requirement, explicit or implicit, of a given job role..

Parental Family: In reviewing the literature on this subject, Payne et al. generalize that "while both the individual's current socioeconomic status and his parental family or lineage status have been found related positively to higher individual rates of membership and participation, the former tends to be a better predictor. However, for children and for those youths and young adults not yet earning their own Iivings, parental family or lineage status is the only meaningful and avallable measure of the individual's own soctoeconomic status." 2 Higher parental family or lineage status is, in general, positively associated with higher rates of organized voluntary group membership, participation, and leadership, as evidenced by studies by Coleman (1961), and Baeumler (1965).

Home Ownership: Home ownership has consistently been

${ }^{1}$ Ibld., p. 218.

2 Ibid., p. 219. 
found to be related to higher rates of membership and participation in voluntary associations by such researchers as Mather (1941), Anderson and Ryan (1943), Scott (1957), Wright and Hyman (1958), Devereux (1960), Babchuk and Gordon (1962), Babchuk and Thompson (1962), and Spiro (1968). Payne et al. comment upon the findings with regard to this variable.

Part of the explanation probably lies in this factor's close association with other elements of socioeconomic status. But some of the explanation probably also is associated with length of residence in the community, since it has been showm that persons of longer residence are higher perticipators than very recent immigrants (Martin; 1952). The element of residential instability, as related to owning vs. renting, is perhaps also involved here. Rentine makes for more residential mobility, which interrupts patterns of affiliation, and causes a person to spend more time as a newcomer to the community, thus reducing participation even if all other factors are held constant. 1

\section{Socio-Physical Characteristics}

The third major social background factor in the framework presented by Payne et al. is that of "socio-physical" characteristics, including the following varlables.

Sex: The reviewers observe that most studies relating sex to membership and participation in voluntary associations have found men to have more membership and participation than women, in the United States. This finding is represented in studies by Lynd and Lynd (1929), Bell (1938), Warner and Lunt (1941), Goldhamer (1942), Komarovsky (1946), Freedman and Axelrod (1952), Bell and Force (1956b), Scott (1957), Wright and Hyman (1958), and others. 
Types of memberships are consistently reported to vary by sex. Women belong to more religious organizations and to more service-oriented voluntarism, according to Schuyler (1959), Lazerwitz (1961), and others. Payne et al. state that this dynamic is changing, noting that "the increase in urbanization, in the number of working women, in the impact of the women's Iiberation movement, and in civil rights legislation, can be expected to increase the rate of membership and active participation of women in those organizations avoided or not accessible to women in the past." 1

Race: The second variable discussed within the sociophysical cluster is that of race. The most salient findings reported in this section indicate that when educational and social class factors are controlled, blacks are more likely than are whites to be active participants in voluntary associations (Orum, 1966). Olsen (1970) replicated Orum's findings and found that voluntary participation rates for American blacks (Cincinnati) on a wide range of indices rose substantially when socioeconomic status and age were controlled.

\section{Formal Organizational Affiliations and Roles}

Work and Occupations: Payne, Payne, and Reddy note that studies have rarely investigated the relationships between work and occupational roles and voluntary group membership and participation, nor has a systematic attempt been made to 
study rates and patterns of participation by and across occupations. They see this area as an important area of analysis in the study of roluntary association participation. Religion: Payne et al. discuss the fact that studies have generally shown that Catholics have been found to have lower non-religious voluntary group participation rates than other religious groups, as demonstrated by studies done by Warner and Lunt (1941), Goldhamer (1942), Komarovsky (1946), Scott (1957), Wright and Hyman (1958), Babchuk and Gordon (1962), and others. However, Catholios have been found to have higher rates of religious participation than do Protestants (Cowhig and Schnore, 1962) and Jews have usually been found to have the highest rates of membership and participation in non-religious organizations (Goldhamer, 1942 and Wright and Hyman, 1958).

Hausknecht's (1962) analysis of national sample surrey data suggests that the main variation between religious groups is in the type of non-religious voluntary assooiations in which members of major religious groups participate. Hausknecht reports that far more Catholics join veterans, patriotic, and military associations than Protestants; that Protestants join civic and service organizations alightly more than Catholics; and that more Protestants than Catholics join economic, occupational, and professional organizations. Political Affiliation: Payne et al. summarize the findings in the literature with regard to this variable by stating that "there is substantial evidence in studies both in the 
United States and in other countries that political activity is associated with membership and participation in nonpolitical voluntary associations." 1 Evidence for this conclusion is drawn from studies by Coser (1951), Hastings (1954), Maccoby (1958), Dahl (1961) and others.

\section{Interpersonal Roles}

Another major cluster of social background factors influencing particlpation in voluntary associations is termed by Payne et al. as "interpersonal roles." They state that studies by Katz and Lazarsfold (1955), Jacoby (1966) and Booth and Babchuk (1969) "have found Important associations between voluntary group memberships or participation and various personal influence patterns and processes. These studies have found that most of ten people join and become involved in roluntary associations because they are personally asked and encouraged to do so rather than through more impersonal means, even though mass media may provide a responsive attitudinal background to be triggered by a personsl request." 2

Evidence Indicates that spouses are especialiy influential upon each other's membership and participation roles in the voluntary organization setting. For example, one spouse may particlpate at the urging of the other, or the

$$
\begin{aligned}
& 1_{\text {Ib1d. , p. } 226 .} \\
& 2_{\text {Ib1d. , p. } 228 .}
\end{aligned}
$$


decision to participate may be a mutual one. This influence is pointed out in studies by Anderson (1946), Babchuk (1965), Hodge and Treiman (1968), Adams and Butler (1967), Harry (1970), and Smith (1972). Babchuk (1965) and Adams and Mogey (1967) note the special influence of the husband in settings where bath spouses participate together.

Furthermore, having a large number of friends and being subject to their influence (Scott, 1957; Devereux, 1960, and Babchuk and Thompson, 1962), knowt ng a large number of ne1ghbors (Smith, 1972), and being involved with fellow workers (Spinrad, 1960) have been other factors found to be assoc1ated with higher rates of membership and participation in voluntary groups.

\section{Migration and Length of Residence}

The final major cluster of social background factors discussed by Payne et al. includes the varlables of migration experience and length of residence in a given community. They assert that these variables "may have a direct influence on social relationships and social participation, since those moving to new neighborhoods, communities, or regions find themselves having to establish new social relations and to join those local groups they are attracted to. This process takes time and the newcomer lags behind longer-time residents. Such is the rationale for the inclusion of measures of migration and length of residence in studies of voluntary 
participation." 1

Studies of communities have generally found that lower rates of membership and participation may be expected for newcomers to a community during the first five years of their residence (Kaufman, 1949; Martin, 1952; Z1mmer, 1955, 1956; Devereux, 1960; Babchuk and Thompson, 1962; Jitoda1, 1965, and Spiro, 1968). Payne et al. point out that "deviant cases may be expected, especially when an organization is the unit of analysis . . For example, Babchuk and Gordon's investigation of a neighborhood improvement councll (1962) revealed that although longer residence favored membership, newer residents of the area tended toward more frequent attendance and were more $11 \mathrm{kely}$ to assume leadership roles." 2 Another finding to note with regard to length of residence is Spiro's finding (1968) that length of residence in a neighborhood is a better measure of membership and participation than is length of residence in the city.

Implications of Social Characteristics Findings for The study

As noted earlier in this review, one of the purposes of the present investigation was to describe the participants in the Evergreen Community Organization in terms of sereral dimensions of social characteristics of demographic variables. The framework of analysis presented by Payne, Payne,

$$
\begin{aligned}
& { }^{1} \text { Ibid., p. } 229 . \\
& { }^{2} \text { Ibid. , }
\end{aligned}
$$


and Reddy as outlined proved to be a comprehensive method of organization for the findings in the literature that became the theoretical bases for the social background issues under investigation in the present surrey. The eramework presented by Payne, Payne, and Beddy enabled the organization of findings relating to the demographic and social characteristics of participants in voluntary organizations into a toplcal outline that is comprehensive in 1 ts soope and flexible enough to provide the begtnnings of the kind of integrative conceptual research that David Horton Smith argues is necessary to the further development of voluntary aotion research. It is possible to utilize this outline not only to organize a review of the literature in this field, but also to generate thought about areas of investigation that should be addrossed in any survey of social characteristics of participants in voluntary assoolations.

ATTITUDINAL AND MOTIVATIONAL DYNAMICS OF PARTICIPATION IN VOLUNTARY ASSOCIATIONS

This section of the review of literature will focus upon findings from the literature which the researchers deemed to be germane to the development of areas of Investigation related to attitudinal and motivational characteristics of the population studied with regard to participation in ECO. The 1iterature selected for inclusion in this survey was that which the authors determinad to be most relevant to the concerns addressed in the present research project, and 
to those findings which influenced the development of the research instrument.

Mulford and Klonglan, ${ }^{1}$ in their analysis of attitude factors relating to individual participation in voluntary organizations, state that "attitudes may be regarded as predispositions to respond, as anticipatory responses to people, orpanizations, and situations, ${ }^{2}$ This definition is accepted as useful perspective by the authors of the present study. Furthermore, Mulford and Klonglan focus their discussion upon two 1ssues that they consider contral to an analjsis of formal voluntary organizations. These two issues are: "(1) the correlation between attitudes and affiliation, and (2) between attitudes and participation in formal voluntary organizations." 3

Given these two central 1ssues, Mulford and Klonglan proceed to review the findings associated with each issue, a framework which has been found to be useful in organizing this review. Before proceeding with the review, it should be noted that Mulford and Klonglan point out that "our knowledge of why people participate in FVos (formal voluntary

${ }^{1}$ Mulford and Klonglan; "Attitude Determinants of Individual Participation in Organized Voluntary Action"; in Smith, Reddy, and Baldwin (eds.) Voluntary Action Research:1972.

$$
\begin{aligned}
& 2_{\text {Ibid. . p. } 251 .} \\
& 3_{\text {Ibid., p. } 252 .}
\end{aligned}
$$


organizations) 18 still quite modest."1 They discuss Beal's (1956) study which noted that most variables utilized in participation research have been of a "static" nature, including the social background or demographic oharacteristics reviowed earlier in this presentation. Beal referred to these variables as "static" because he san them as variables which could not be readily changed by a social action professional, a member, or a leader. His study of participation In farmers' cooperatives was one of the first to emphasize both static and dynamic variables and his major finding was that dynamic (attitudinal) variables were more predictive of participation than were social background ractors. Therefore, Beal argued for causative models utilizing many variables with analysis focused upon linkages between these variables in predicting participation in FVOs. Mulford and Klonglan point out that Beal's suggestions were largely unheeded and that the need for research which deals with both social background and attitudinal (static and dynamic) variables is pressing. The present study is an effort at a descriptive analysis utilizing both types of variables.

\section{Attitudes as Correlates of Affiliation}

Beal's 1956 study of participation in farmers' cooperatives, one of the first to deal with attitudinal variables, found that the following factors were significantly related to participation:

${ }^{1}$ Ib1d. 
(1) Understanding of cooperative principles.

(2) Satisfaction with the cooperative.

(3) "Having a say" in cooperative affairs.

(4) Knowledge of the cooperative.

(5) Feeling responsible to the cooperative.

(6) Identification with the cooperative.

(7) Feeling the cooperative is 'their agent'.

(8) Feeling the cooperative is acceptable in terms of the group's general value system.

Harp (1959) developed three hypotheses that were tested and supported with the original Beal data. The hypotheses were:

(1) Participation varies directly with satisfaction,

Satisfaction varies directly with understanding, and (3) Participation is directly related to understanding.

Findings by Downing (1957) and Scott (1953) show that attitudes indicating a feeling of necessity for the existence of a specific FVO are correlated with participation. In other words, people will be more likely to particlpate when they feel that it is necessary for the organization to exist to serve some purpose. Also, with reference to Beal's atudy, his findings related to "having a say", or one's perceptions about his or her power to influence the social structure, has continued to interest researchers.

\section{Attitudes Toward the Community}

The variable of participants' attitude toward the community has been studied by several researchers. Mulford and Klonglan indicate that Devereux (1960) "found that Identification with the community and community evaluation were related to participation in FVOs and to politioal participation. . those who participate in many FVOB are most 
likely to state that they do this because it is a duty to the community. High participators are more likely to be... interested in local and national affairs. Low participators are more likely to be 'localite' in their orientations.... often uninterested in either local or national affairs." 1

Some researchers have investigated the relationship between the sense of community obligation and participation. For example, Nelson et al. (1969) developed a scale to measure the attitude "commitment to solve community problems." Mulford and Klonglan suggest that "middle-class citizens who participate in FVOs tend to do so because of their farorable attitudes toward the community and because of their sense of obligation to their community." 2

In a related study, S1lls (1957) found that volunteers who participated in the March of Dimes stated that they recelved: (1) satisfaction from being able to accomplish shortterm goals they helped to set, (2) a change to put into practice organizational skills possessed, and (3) satisfaction from creativity.

The Relative Importance of General and Specific Attitudes

David H. Smith's (1966) study of membership and participation in associations in Santiago, Chile is one of the few studies which has utilized simultaneously socioeconomic,

\footnotetext{
${ }^{1}$ Ibid. . p. 256.

2 Ibld.
} 
attitudinal, and personality dimensions. Mulford and Klonglan point out that Smith obtained measures of general and specific attitudes relevant to FVOs, finding that general and specific FVO attitudes were the most important discriminators of FVO members from non-members.

The general FVo-relevant attitudes that discriminated between members and matched eligible nonmembers were: (1) general obligation to participate in FVOs, (2) general FVO instrumental value, (3) formal group preference, and (4) service orientation to leisure time. Members were also found to be more involved in informal relations and church attendance than non-members.

Specific FVO relevant attitude scales that discriminated significantly between members and eligible non-members were: (1) commitment to the specific FVO, (2) perceived efficacy of the specific FVo to achieve its goals, (3) felt obligation to participate in the FVO, (4) attractiveness of the FVo, (5) significant outside personal support for the FVO, (6) perceived personal fit with the FVO, (7) friendliness with people in the FVO, and (8) whether the person was influenced or recommended to join the specific FVO.

In his later study of eight Massachusetts towns, Smith (1972) utilized these attitudinal variables and found the same general FVO attitude variables to be important in discriminating between membership and participation levels of persons. Smith was one of the first researchers to outline attitudinal variables along general and specific FVO IInes of investigation.

Attitudes as Correlates of FVO Participation Among Members

Mulford and Klonglan discuss "effectiveness of the organization" as a variable which is associated with attitudes

${ }^{1}$ Ib1d., p. 259. 
of members regarding organizational participation. They point out that this variable has been largely neglected by researchers and they argue for further study of the relationships between members' attitudes and organizational effeotiveness. There are, however, a few studies which have examined this important dimension.

Attitudes Associated with Continued and Active Participation, Harp and Cummings (1968) and Davis (1961) have studied the activity and survival of small discussion groups. Their conclusions were that homogeneity of attitudes probably makes for participation and continuity in expressive type organizations, but that diversity of attitudes probably makes for continuity of participation in instrumental type groups. In a related finding, Brooks et al. (1969) stated that when members of formal voluntary organization have the attitude that the organization's goals are intangible and the roles of members are ambiguous, goal displacement is likely to occur. In other words, intanglble goals and ambiguous roles lead members to leare the organization.

Smith's (1956) study (cited earlier) discriminated active from inactive members of several FVOs by utilizing general and specific FVo-relevant attitudes, personality dimensions and socioeconomic factors. Smith's findings with regard to this issue are summarized by Mulford and Klonglan:

General FVo-relevant attitudes that significantly discriminated active from inactive FVO members were: (1) a general obligation to participate in FVOs, (2) a general perception of the instrumental value of 
Fvos, (3) formal group preference, and (4) a service orientation to leisure time.

Smith found that elght specific FVO-relevant attitudes discriminated active from inactive members: (1) percelved rewards for participation, (2) perceived social support within the FVO, (3) commitment, (4) perceived attractiveness, (5) felt obligation to participate, (6) percelred personal fit with the PVO, (7) percelved efficacy of the specific FVO, and (8) outside significant-other support for participation in the FVO.1

Internal Communication and Decentralized Power as Requisites to Activity and Erfectiveness

Several researchers have developed hypotheses about members' att1tudes toward internal functioning of FVOs. In general, the finding has been that high degrees of internal communication and decentralized or shared power will lead to active and effective FVOs. Several studies of local Leagues of Women Voters have been used to generate this finding. For example, Likert (1961) found the following attitudes to be characteristic of active and effective local Leagues: (1) pressure to participate comes from self or other members, not from officers, (2) feelings that members have influence, and (3) feellngs that boards keep them informed and that offlcers are interested in them.

Smith and Brown (1964) have also studied the actirity and effectiveness of $10 c a l$ Leagues, flnding that decentralization of control and total control are both correlated with activity and effectiveness. Decentralized control means that members at each level feel they have pover, while total control scores for each League were developed by adding the 
amount of percelved control across all levels.

Copp (1964) studied the dimension of loyalty to the organization (farmers' cooperatives, in this case) as an attitudinal factor crucial to participation. Loyalty 18 considered to be members' willingness to remain in the FVo. Copp found that loyalty predicted these aspects of continued member participation: (1) compulsion to recruit others, influence a member feels he has in the cooperative, (3) acceptance of cooperative doctrine, and (4) satisfaction with cooperative doctrine. Copp found loyalty to be a better predictor of continued activity than knowledge or prior participation.

Inducements, Contributions, and Continued Participation

Mulford and Klonglan introduce this section by noting their previous observations that many people are led to affiliate with FVOs because they feel they may personally profit. They proceed to develop a review of studies of what they consider to be "one of the most promising theoretical developments (in voluntary action research on attitudes). ... the implications of inducements/contributions hypotheses."1 Philifps (1969) developed and tested two inducement/ contributions hypotheses while studying FVo participation. These hypotheses were: "(1) greater FVO particlpation will be associated with a greater number of positive feelings, and (2) the

$$
{ }^{1} \text { Ibid., p. } 263 .
$$


greater the extent of happiness (positive feelings minus negative ones), the greater will be the degree of participation and contribution in FVOs." 1 Both of these hypotheses were supported by Phillips' findings and the correlation between the number of positive feelings and participation holds for all social classes.

In 1967, Warner and Heffernan conducted what they termed a benefit-participation contingency study with voluntary farmer organizations. Their findings suggest that it is not the absolute number of benefits of participation that is significant, but rather it is the ratio of benerits to contributions with regard to participation that is most sallent. Warner and Heffernan favor an "exchange theory" model of study of voluntary associations, emphasizing such elements of organizational analysis as: (1) non-benerit factors (duties, coercion, commitment, etc.), (2) costs of partiolpation, and (3) alternatives available to members, with the emphases on analyses at both the individual member and the organizational levels.

A final dimension of analysis with regard to this section is the observation by Tannenbaum and Backman (1966) that those who are most active in FVOs are likely to hold attitudes that are unfform. They argue that "attitude uniformity" is one measure or aspect of "groupness" as derined by Smith (1967). Tannenbaum and Backman found that, in their

\section{Ibid.}


study, officers tended to be most uniform in attitudes, followed by active members, with inactive members showing the least uniformity of attitudes.

Mulford and Klonglan conclude their efforts at a review of the literature by summarizing the major FVO-relevant attitude types which they found in their research. They distinguish broadly between general and specific FVo-relevant attitudes as follows: "General attitudes are thought to apply across a broad range of voluntary action settings and related social situations; and they are distinguished from specific attitudes concerning and centering on a particular FVO."1

General FVO-Relevant Attitudes: Mulford and Klonglan point out that many of the suggested types of general FVOrelevant attitudes have been largely ignored by researchers, including (1) attitudes regarding the influence of one's "significant others", and (2) dimensions of personal experience with FVOs in general. Several researchers, however, have studied attitudes that focus on a personal sense or relation to FVOs in general, and on an individual's attitudes toward organized activities. Mulford and Klonglan cite studies by Wilson (1954), Freeman et al. (1957), Jesser (1967), and Schwirian and Helfrich (1968) which report moderate to strong relationships between FVO activity and attitudes indicative of a personal sense of relation to Fvos in general-usually emphasizing presence of attitudes relating 
to a general commitment to organized voluntary aotion or to the community.

Specific FVO-Relevant Attitudes. Mulford and Klonglan note that "specific attitudes have received relatively more attention by researchers, especially those related to FVO characteristics and personal experience with the specific FVO." They summarize research related to specific FVOrelevant attitudes.

Smith (1966), Beal(1956), Harp (1959), Dowing (1957), and Scott (1953) found strong relationships between FVO characteristics (usually, stated need, effectiveness, personal fit, and attractiveness) and affiliation. Smith $(1966)$ also found strong relationships between others' specific FVo influence and affiliation... Beal (1966), Smith (1966), Cooper (1961), and Lars on and Cottan (1961) have found strong relationships between specific attitudes that focus on personal experiences related to the FVO and affiliation with that FVO.

Beal (1956), Smith (1966), Copp (1964), and S1118 (1957) obtained strong relationships betwoen FVo affiliation and specific attitudes which focus upon a persional sense of relation (commitment) to the specific FVO. Smith (1966), Sills (1957), and Devereux (1960) reported strong relationships between the individual's attitudes toward his activities in a specific FVO and participation in that FVO.

Smith (1966) found a strong relationship between eight specific attitudes and continued, active part1cipation: (1) rewards for participation, (2) sooial support, (3) commitment, (4) attractiveness, (5) obligation to participate. (6) personal fit with FVo, (7) efficaoy of specific FVo to achieve its goals, and $(8)$ outside significant-other support for the FVO. 1

Mulford and Klonglan conclude their disoussion by making recommendations for further researoh utilizing a

$1_{\text {Ibid., pp. } 267-68}$ 
systems approach that "would allow us to incorporate existing data and knowledge with additional required data in a meaningful manner, including such inputs as (1) socioeconomic variables, (2) attitudes, (3) personality dimensions, and (4) the degres of selectivity used to recruit members." 1 Also, Mulford and Klonglan suggest that "future research which focuses upon interorganizational relations could consider the degree to which members of FVOs hold homogenous attitudes with regard to themselves, the role of FVOs in their community and attitudes toward their community." 2

\section{SUMMARY OF LITERATURE REVIEW}

The authors of this study have selected two major areas of investigation with regard to the study of participation in the Evergreen Community Organization: sociodemographic characteristics of participants, and attitudinal dynamics of particlpation in communtty affairs in general and in ECO as a specific organization. While much of the material presented in the foregoing review is not directly related to participation in a community organization, the authors believe that much of the literature relating to the field of partiolpation in voluntary associations is generio and therefore applicable to the study of participants in a wide-range of voluntary associations. Most of the roluntary action research is, as

$$
\begin{aligned}
& { }^{1} \text { Ibid., p. } 270 . \\
& { }^{2}{ }_{\text {Ibid., p. }} 271 .
\end{aligned}
$$


pointed out by Smith and by Mulford and Klonglan, speoifio to the study of a given organization, and this study 18 no exception. Smith's book is the first major attempt to organize voluntary action research into a comprehensive body avallable to researchers and scholars in the rleld. Given the overview of Iiterature pertaining to the concerns and foci of the present research, it was possible for the authors to develop a conception of the areas of research that were most relevant to a descriptive sudy of the participants in the Evergreen Community Organization and to proceed ith development of the research ingtrument. 


\section{CHAPTER III}

\section{METHODOLOGY}

The methods employed to select and describe the population under study will be indicated and discussed in this section. Topics to be considered include a desoription of the process used to select the population of "active" ECO members to be studied. Development of the interview schedule, issues of interviewer reliability, pre and post-interview contact with respondents, and methods employed in the analysis of the data will be described and examined.

The population studied included all "active" members of the Evergreen Community Organization (with a few exceptions, which will be discussed later). It was therefore necessary to establish criteria for the definition of "active" members. Since the organization had held five general meetings by the time the population selection was occurring, and since roll lists of members had been collected by the organization's secretary at four of these meetings (at the request of the researchers), it was decided that any person attending three or more of these meetings would be defined as "active" for purposes of this study.

The chalrpersons of the three committees of the organization were asked by the researchers to name the members of 
their committees whom they felt could be desoribed as "active", having helped with the committee work and/or attended committee meetings with some regularity. (It should be noted that most of the organization's work was occurring in these committee meetings at this time, rather than in general ECO meetings). These people, as defined by chairpersons of their committees, also met the criteria of "active" membership for the purposes of this study. The population thus defined included twenty-six people who had either attended three or more general ECO meetings when roll was taken, or had been defined as "active" by the chalrperson of a committee. It should be pointed out that some mombers met both criteria for definition as "active", while others met only one of the criteria.

There were several exclusions from the original population, including the two researchers, who had attended the general meetings and were active on a committee. Others excluded were three persons who formally dropped out of the group after having been described by committee chairpersons as "active". One member of the original population had moved out of state by the time the interview was administered in October 1975, making it impossible to interview that person, who was also excluded from the researoh population.

The population was therefore twenty persons at the time the interview was administered. It is interesting to note that the population included four married couples in which 
each spouse met the criteria of being "active". In tho analysis of data this variable had to be taken into account when describing and interpreting certain responses in the interview.

An interview schedule was constructed in several steps by the researchers. First, the findings in the literature were examined for relevance to the aspects of voluntary association being studied with regard to ECO. Having identified the most relevant issues, the researchers wrote questions about those issues, including both demographic and social background issues as well as attitudinal issues with respect to participation in the organization. This version of the questionnaire was revised twice and tested by the researchers with each other and with their spouses to check for misleading questions, and time frame. After a third revision, the twenty to thirty minute interview was pretested.

The pretest population included five people who had attended two general ECO meetings or who had been defined by committee chairpersons as "active" but had withdram from the organization by the time that the pretest was administered in September 1975. Members of the pretest population were phoned by the researchers, who identified themselves and asked respondents if they would participate in a survey about ECO members. Each member of the population agreed to participate and was interviewed by one of the researchers at the respondent's home. The results of the pretest were used 
to make a final revision of the research instrument. It is important to point out some of the features of the revised interview schedule, as well as to describe its development. Before administering the pretest, the researchers examined each question for wording, phrasing, and intent, in order to come to agreement on how to ask the questions, the definitions of terms, and on how to respond to anticlpated questions about the interview items. This examination of items and agreement on wording, meaning, and techniques of interviewing was an effort to insure the greatest possible degree of interviewer reliability. To arrive at the order of questions for the interview schedule, the researchers independently arranged the questions, then compared the results and made changes to arrive at a $\log 1$ cal and mutually agreed upon sequence.

The final form of the interview schedule was the product of the revisions made before and after the pretest. The schedule (see Appendix I) includes both demographic/social background and attitudinal questions with respect to various aspects of participation in ECO. Both open-ended and forcedchoice items were utilized, depending upon the nature of the question being asked and the possible responses. Interview schedules were coded by the researchers to insure confidentiality. Questions about the University of Washingtion consultants were included in an effort to generate data that might be helpful to the Division. These questions are 
peripheral to the main point of the study (participation in a voluntary association), but it is useful data for the consultants to examine.

The following observations with regard to various items in the construction of the interview should be noted:

(1) The authors believe that "housewife" is an occupational category and 1 t was treated as such in questions dealing with occupation and work.

(2) Unless otherwise worded in the interview schedule, all questions were to be answered as of the date of the interview (for example: age, income, occupation). Some questions pertained only to past events and were so worded (for example: "When you joined ECO, what was Evergreen's main problem?").

(3) In cases where wording in questions was not clearly defined, the researchers developed mutually agreed upon definitions for the purposes of interviewing. In some instances, such as question \#28 ("Have you actively campaigned for any candidate within the past four years?"), it was left to the respondent to determine the meaning of "actively" as he or she percelved it, and then to determine whether he or she felt that that criterion was met.

(4) Question \#23 involved a somewhat lengthy list of community issues which the researchers assembled from former community surveys and from lists of issues generated at ECO meetings. These items were put into random order by drawing 
them by lot. The first item originally drawn was "Law Enforcement and Corrections". Since one of the researchers is will known in the community with regard to this issue, it was decided to exchange this item with another ("Geriatrics and Nursing Homes"), in order to minimize the possibility of strong interviewee reaction to the placement of this item at the top of the list, given the possibility that the respondent might be aware of the connection of the researcher to the field of law enforcement. Also, with respect to this item, the researchers agreed to read the list in reverse order on alternate interviews in order to minimize the possibility of early asked items being uniformly rated either higher or lower by respondents. In order that respondents would not forget the response choices asked for in this lengthy question, a card with the possible answers written on it was given to the respondent.

(5) In an attempt to neutralize the potentially sensitive issue of asking about family income, the researchers letter coded income categories, handed the respondent a card, and asked only for the coded letter whlch corresponded to annual family income. The income levels were not 118 ted on the interview form, and the card was not collected until the end of the interview when it was picked up along with the two other response cards used.

(6) Because of the number of choices and the length of each answer to question \#59 (regarding how others viewed the 
participant's activity in ECO), a card with number-coded response choices was given to the respondent to study and from which to choose an answer.

(7) The final question (\#62: "Do you have any other comments you'd like to make concerning the kinds of things we 've been discussing?") was included not so much to gather data as to give the respondent a chance to verbalize anything he or she felt strongly about which might not have been covered in the interview.

After development of the interview schedule was completed, letters were sent to the interviewees approximately ten days before the interviewing was to begin. The letter set forth the purpose of the study, emphasized confidentiality, and stated that appointments for interviews would be made by telephone. (See Appendix II for Text of letter) Several days later, the researchers telephoned the interviewees and arranged for a half hour interview to be held in the interviewee's home at a mutually convenient time. The researchers had some minimal difficulty in arranging interviews because of the full schedules and limited free time that people who are "active" in voluntary associations tend to have, as well as because of the $11 \mathrm{mited}$ amount of time available to the researchers, who were full-time graduate students at the time of the survey. One respondent, a busy professional person, reluctantly agreed to be interviewed only if the interview could occur during the respondent's 
dinner hour.

The interviews were held by the researchers within a two week period in an attempt to minimize possible data contamination, the likelihood of which would have increased with time as mutual acquaintances had opportunities to discuss the interviews with each other. In the case of married couples, the interviews were scheduled to occur at the same time and each researcher interviewed one of the spouses. In these cases, the interviews occurred in different rooms so that the spouses did not hear each other's responses. In one case, the couple agreed to an interview time but one spouse was not present when the researchers arrived for the interview. It was decided to go ahead and interview the spouse who was at home, and an appointment was made for the other spouse to be interviewed a few days later. The person who was interviewed agreed not to discuss the interview with the absent spouse. The interviews themselves proceeded smoothly, with the main resistances developed around the issue of age with female respondents. Some female respondents emphasized the word "about" when responding (the researchers asked: "What is your approximate age?"), some appeared to be somewhat embarrassed in answering the question, and one respondent would answer only with the word "legal".

other problems included the inability of one respondent to answer the question on priority of projects upon which 
ECO should work. The interviewee indicated that she did not feel closely enough involved either with the community or the organization to make such a determination. Another interviewee did not know what the family income level was. Since the spouse of this interviewee was also a member of the population, the income data was taken from that questionnaire for purposes of data analysis.

All respondents were thanked for their cooperation at the close of their interview. After all interviews were completed, a letter thanking the respondents, emphasizing confidentiality, and indicating plans for presenting results of the study was sent to each respondent (See Appendix III). The data obtained in this descriptive study was analyzed by the researchers using frequency tables and measures of central tendency, where appropriate. Open-ended question responses were categorized for analysis by a process of discussion and joint agreement as to the categories and classin flcation of responses. 


\section{CHAPTER IV}

\section{RESULTS}

The resuits of the study are presented utilizing the outline of social background and attitudinal factors discussed in the review of literature. Some material will be presented narratively; however, the majority of the information will be presented in tables.

The first topic to be considered is what Payne et al. call "Life Cycle Stage." Subsumed in that category are several variables, the first being age. The following table presents the approximate ages of respondents when the interviews were conducted.

TABLE I

AGE OF "ACTIVE" ECO MEMBERS

\begin{tabular}{|cccc|}
\hline Age & Number of Respondents & $\begin{array}{c}\text { Number of } \\
\text { females }\end{array}$ & $\begin{array}{c}\text { Number of } \\
\text { males }\end{array}$ \\
\hline 27 to 30 & 3 & 3 & \\
30 to 35 & 6 & 4 & 2 \\
35 to 40 & 4 & 3 & 1 \\
40 to 45 & 3 & 1 & 2 \\
45 thru 50 & 3 & 1 & 2 \\
"legal" & 1 & 1 & 7 \\
\hline Total & 20 & 13 & \\
\hline
\end{tabular}


The youngest "active" ECO member is 27, with most of the respondents in the 30-45 age bracket. Mean ages, computed from continuous data, are 37.0 years for the entire population interviewed; 39.6 for males, and 35.7 for females. (The female giving her age as "legal" was arbitrarily assigned the age of her husband in computing mean ages.) In general, the population is in the child-rearing stage. Marital status is the second component of Life Cycle Stage. Of the population of 20 , there were 18 married interviewees, or 90\%. One person was separated; one, divorced. The second variable to be addressed is number of children. The following table reflects the number of children each respondent has.

TABLE II

NUMBER OF CHILDREN "ACTIVE" ECO MEMBERS HAVE

\begin{tabular}{|ccc|}
\hline Number of Children & Number of Respondents & $\begin{array}{c}\text { Percent } \\
(f)\end{array}$ \\
\hline 0 & 1 & $5 \%$ \\
1 & 3 & $15 \%$ \\
2 & $5 \mathrm{~A}$ & $25 \%$ \\
3 & 2 & $10 \%$ \\
4 & $4 \mathrm{~A}$ & $20 \%$ \\
6 & $4 \mathrm{~B}$ & $20 \%$ \\
\hline Total & 1 & $5 \%$ \\
\hline
\end{tabular}

A This includes one married couple. 
No age limits defining "children" were set, so some of these "children" might be considered adults, as noted later in this discussion. The mean number of children per household is 3 , and the total number of children with one or both parents included in this study is 45 . (Children of married couples in which both members were interviewed were counted only once.)

Age of children is the third factor for consideration, and the ages of the children in the previous table are noted in this table.

TABLE III

AGES OF CHILDREN OF "ACTIVE" ECO MEMBERS

\begin{tabular}{|cc|}
\hline Age & $\begin{array}{c}\text { Number of Children } \\
\text { (f) }\end{array}$ \\
\hline Under 3 & 3 (toddlers) \\
3 to 5 & 1 (pre-school) \\
5 to 13 & 19 (elementary) \\
13 to 16 & 9 (Jr. High) \\
16 to 19 & 4 (High School) \\
19 to 23 & 5 (College) \\
23 to 28 & 45 \\
\hline Total & \\
\hline
\end{tabular}

As mentioned previously, some of the children of "active" ECO members are now adults. In this table each child is listed only once in the cases of married couples where both members were interviewed. One additional factor of Life Cycle Stage which is specific to this study was not included by Payne et al. but 
will be discussed here because of its relevancy to this study. This factor is the number of children of the respondents who are currently attending public schools. The following table indicates hou many interviewees have children in the public schools.

\section{TABLE IV}

PUBLIC SCHOOL ATTENDANCE OF "ACTIVE" ECO MEMBERS ' CHILDREN

\begin{tabular}{|cc|}
\hline $\begin{array}{c}\text { Number of Children } \\
\text { in Public Schools }\end{array}$ & $\begin{array}{c}\text { Number of Respondents } \\
\text { (f) }\end{array}$ \\
\hline 0 & $3^{*}$ \\
1 & $4^{*}$ \\
2 & $4^{*}$ \\
3 & $3^{*}$ \\
4 & 1 \\
\hline Does not apply & 20 \\
\hline Total number of respondents & \\
\hline * This includes one married couple.
\end{tabular}

There are a total of 29 children in public schools. (Children of married couples in which both members were interviewed were counted only once.). Of the 16 children not in public schools, 11 have already completed public schooling. It is revealing to note, however, that $80 \%$ (16) of the respondents currently have chlldren in the public schools, and the mean number of such children in each family is 2 .

The second major heading of Social Background Pactors is Socio-Economic Status, according to payne et al. The first variable to be considered is income. Total family income of the respondents is indicated in the following table. 
TABLE V

TOTAL TAMILY INCOME OF "ACTIVE" ECO MEMBERS

\begin{tabular}{|ccc|}
\hline Income Level & Number of Respondents & $\begin{array}{c}\text { Percent } \\
(\mathrm{f})\end{array}$ \\
\hline (1) $\$ 10,000-\$ 14,999$ & 8 & $40 \%$ \\
$(2) \$ 15,000-\$ 19,999$ & 5 & $25 \%$ \\
$(3) \$ 20,000-\$ 24,999$ & 4 & $20 \%$ \\
(4) $\$ 25,000-\$ 29,999$ & 2 & $10 \%$ \\
Don't Know & $1^{*}$ & $5 \%$ \\
\hline Total & $20^{-}$ & $100 \%$ \\
\hline
\end{tabular}

* This respondent's spouse reported family income at $\$ 25,000-\$ 29,999$.

Both the median and mean family income is $\$ 17,500$. Perhaps the most striking feature of this table is the relative homogeneity of the population. There are no respondents at the poverty level nor are there any who could be classified as wealthy.

Education is the second factor to consider. The following table summarizes the education of both the respondent and that person's spouse. 
TABLE VI

EDUCATIONAL LEVEL OF "ACTIVE" ECO MEMBERS AND THEIR SPOUSES

\begin{tabular}{|c|c|c|c|}
\hline Level of Education & Number & $\begin{array}{l}\text { of Respondents } \\
\text { (f) }\end{array}$ & $\begin{array}{l}\text { Number of } \\
\text { Respondents' } \\
\text { Spouses (f) }\end{array}$ \\
\hline H1gh School & & 1 & 3 \\
\hline $\begin{array}{l}\text { Beyond High School } \\
\text { but no university } \\
\text { degree }\end{array}$ & & 8 & 7 \\
\hline University graduate & & 3 & 3 \\
\hline $\begin{array}{l}\text { Post-college work } \\
\text { including Master's } \\
\text { degree }\end{array}$ & & 8 & 5 \\
\hline Total & & 20 & 18 \\
\hline
\end{tabular}

No attempt was made in this table to consider responses of the married couples in which both members were interviewed. There are 8 persons, then, who appear in both columns of the chart simultaneously. There appears to be little difference in the educational level of participants and their spouses, but both in general tend to have more than the average number of years of education.

Occupational status is the next item in the framework. The following table shows the occupation of the "active" ECo members and their spouses. 
TABLE VII

TYPE OF WORK OF "ACTIVE" ECO MEMBERS AND THEIR SPOUSES

\begin{tabular}{|lcc|}
\hline Type of Work & $\begin{array}{c}\text { Number of Respondents } \\
(f)\end{array}$ & $\begin{array}{c}\text { Number of } \\
\text { Respondents } \\
\text { Spouses (f) }\end{array}$ \\
\hline $\begin{array}{l}\text { Housewife } \\
\begin{array}{l}\text { Part-time } \\
\text { Education }\end{array}\end{array}$ & 9 & 4 \\
$\begin{array}{l}\text { Full-time } \\
\text { Education }\end{array}$ & 2 & 4 \\
Professions & 5 & 4 \\
Skilled laborer & 3 & 4 \\
Sales & 1 & 2 \\
\hline \multicolumn{1}{|c|}{ Total } & 20 & 18 \\
\hline
\end{tabular}

No attempt was made in this table to consider responses of the married couples in which both members were interviewed. There are 8 persons, then, who appear in both columns of the chart simultaneously. Relatively fow blue collar workers appear in either column.

The researchers did not pursue the matter of family or lineage status in part because of perceived high mobility in the area and the resultant lack of family ties, and because of the lack of any percelved ethnic based status differences in the area.

Home ownership is the next issue to be addresses. Homes either are owned or are being purchased by 18 of the 20 respondents. The other 2 interviewees are renting. This 
means that $90 \%$ of the population interviewed are home owners. One additional factor which will be discussed here, although Payne et al. did not include 1t, 18 school attendance area. The following table shows the number of respondents residing within each elementary school area in 1974-75. It also shows the percent of students on free and reduced price lunches as a measure of the socio-economic level of that attendance area.

\section{TABLE VIII}

ELEMENTARY SCHOOL AREAS IN WHICH "ACTIVE" ECO MEMBERS RESIDE AND THESE AREAS' PARTICIPATION IN

FREE AND REDUCED PRICE HOT LUNCHES

IN 1974-75

\begin{tabular}{|c|c|c|}
\hline Elementary School Area & $\begin{array}{l}\text { Percent of Students } \\
\text { Recelving Free or } \\
\text { Reduced Price Lunches }\end{array}$ & $\begin{array}{c}\text { Number of } \\
\text { Respondents } \\
(f)\end{array}$ \\
\hline $\begin{array}{l}\text { Marrion } \\
\text { Ellsworth } \\
\text { Crestline } \\
\text { Burton } \\
\text { Mill Plain } \\
\text { Silver Star } \\
\text { Orchards } \\
\text { Sifton }\end{array}$ & $\begin{array}{l}11.7 \% \\
13.2 \% \\
13.8 \% \\
13.8 \% \\
17.3 \% \\
24.8 \% \\
28.5 \% \\
32.8 \%\end{array}$ & $\begin{array}{l}1 \\
1 \\
6 \\
5 \\
2 \\
2 \\
3 \\
0\end{array}$ \\
\hline Total & & 20 \\
\hline
\end{tabular}

* This information was supplied by the Evergreen School District Office.

With regard to school attendance area, there are few "active" ECO participants residing in the areas which have either the highest or lowest percentages of students receiving free or reduced price lunches. 
Attention will now be given to the area of SocioPhysical Characteristics, Of those discussed by Payne et al. only 2 will be dealt with here; those of sex and race. All of the members of the population surveyed are white. of the 20 people involved, 13 are women and 7 are men. The next major topic to consider is Formal organizational Affiliations and Roles, and the first area within this category is that of occupation and work. The variable under consideration here is not that of occupational status (as discussed earlier), but rather the concern is with how occupation itself may predispose people to various forms of participation.

The issue which is relevant to ECO with regard to this variable is the significant ties to education as an occupation by $50 \%$ of the population studied. In fact, 10 respondents are connected with education either through their own occupation or that of their spouse. Of these 10,6 are directly connected with education in the Evergreen Schools by either their own or their spouse's employment.

Religion is the second aspect of organizational affillation which Payne et al. mention. The religious preference of the respondents is indicated in the following table. 
TABLE IX

RELIGIOUS PREPERENCE OF "ACTIVE" ECO MEMBERS

\begin{tabular}{|lcc|}
\hline Religious Preference & Number of Respondents & $\begin{array}{c}\text { Percent } \\
(\mathrm{f})\end{array}$ \\
\hline Methodist & 6 & $30 \%$ \\
Lutheran & 3 & $15 \%$ \\
Episcopal & 2 & $10 \%$ \\
Christian Science & 2 & $10 \%$ \\
Mormon & 1 & $5 \%$ \\
Protestant & 1 & $5 \%$ \\
No preference & 5 & $25 \%$ \\
\hline Total & 20 & $100 \%$ \\
\hline
\end{tabular}

There are no Roman Catholics or Jews in the population which is predominantly protestant $(70 \%$, or 14 respondents) with $25 \%$ expressing no preference.

The only other topic mentioned by Payne et al. regarding organizational affiliation which will be discussed here is that of politics. Several tables are relevant to political activity, and the first to be presented will be one which summarizes general types of political activity such as voting and campaigning. 
TABLE X

POLITICAL ACTIVITY OF "ACTIVE" ECO MEMBERS

\begin{tabular}{|c|c|}
\hline Activity & Number of Respondents $(f)$ \\
\hline Registered voter & 20 \\
\hline Voted within past year & 20 \\
\hline \multicolumn{2}{|c|}{ Political Party Affiliation } \\
\hline $\begin{array}{l}\text { Yes } \\
\text { No }\end{array}$ & $\begin{array}{r}16 \\
4\end{array}$ \\
\hline \multicolumn{2}{|c|}{$\begin{array}{l}\text { Circulated Initiatives or } \\
\text { Petitions within past } 2 \\
\text { years }\end{array}$} \\
\hline $\begin{array}{l}\text { Yes } \\
\text { No }\end{array}$ & $\begin{array}{r}13 \\
7\end{array}$ \\
\hline \multicolumn{2}{|c|}{$\begin{array}{l}\text { Campalgned Actively for a } \\
\text { Candidate within past } 4 \\
\text { years }\end{array}$} \\
\hline $\begin{array}{l}\text { Yes } \\
\text { No }\end{array}$ & $\begin{array}{r}12 \\
8\end{array}$ \\
\hline
\end{tabular}

(Horizontal Iines indicate separate questions)

Given the fact that Washington has an open primary which makes political party affiliation voluntary and a bit more formal than a simple declaration, it is of interest to note that $80 \%$ of the population studied (16 respondents) are affiliated with a political party. All are registered voters and have voted in the past year, and over half have circulated initiatives and petitions and campaigned for a candidate recently.

In this regard, the following table indicates the 
number and types of candidates campaigned for by the interviewees.

\section{TABLE XI}

NUMBER AND TYPES OF CANDIDATES "ACTIVE" ECO MEMBERS CAMPAIGNED FOR IN THE LAST 4 YEARS

\begin{tabular}{|cc|}
\hline Candidates & Number of Respondents (f) \\
\hline $\begin{array}{l}\text { Number of Candidates } \\
\text { campaigned for: }\end{array}$ & 8 \\
None: & 5 \\
1 & \\
2 & 3 \\
3 & 3 \\
4 & 1 \\
5 & \\
Type of Candidate & 4 \\
campaigned for: & 2 \\
President & 5 \\
State legislator & 10 \\
County official & 3 \\
City official & 8 \\
School board member & 32 \\
Total & $4908 t$ \\
\hline
\end{tabular}

(Horizontal lines indicate separate questions)

* One of these respondents ran for office. 
It appears that those who campaign for candidates do so at the local level primarily. of the 32 candidates supported, $21(66 \%)$ were county, city, or school district candidates.

The final table to be presented in relation to political activity indicates the type and number of public meetings attended by participants.

TABLE XII

TYPES AND NUMBER OF PUBLIC MEETINGS ATTENDED IN THE PAST YEAR BY "ACTIVE" ECO MEMBERS

Meetings Number of Respondents ( $f$ )

Type of meetings attended*

State legislative sessions and/or hearings 4

State Commission hearing 1

Planning meetings 5

County Commissioner's meetings 7

County boards 1

School board 16

Number of meetings attended

None 4

Less than 3

2

$3-10$

8

$11-20$ 2

over 20

4

* Multiple responses possible for this question

(Horizontal ines indicate separate questions) 
As indicated above, $80 \%$ of the population (16 respondents) attended some kind of public meeting; and further, every one of those respondents attended at least one school board meeting.

An issue relating to formal organizational affiliations not included in the Payne et al. outline is that of membership in other community or service organizations held by the "active" ECO members and their spouses.

\section{TABLE XIII}

MEMBERSHIP IN COMMUNITY OR SERVICE ORGANIZATIONS OF "ACTIVE" ECO MEMBERS AND THEIR SPOUSES

\begin{tabular}{|c|c|c|}
\hline Type of Organization & $\begin{array}{l}\text { Number of } \\
\text { Respondents ( } f \text { ) }\end{array}$ & $\begin{array}{l}\text { Number of } \\
\text { Spouses }(f)\end{array}$ \\
\hline $\begin{array}{l}\text { Evergreen Community } \\
\text { Groups }\end{array}$ & $14 \mathrm{~A}$ & $16^{\mathrm{B}}$ \\
\hline $\begin{array}{l}\text { Education Groups (such } \\
\text { as PTAs) }\end{array}$ & 3 & 3 \\
\hline Service Organizations & 5 & 4 \\
\hline Civic Groups & 3 & 2 \\
\hline $\begin{array}{l}\text { Advisory or Executive } \\
\text { boards }\end{array}$ & 2 & 4 \\
\hline No memberships & 3 & 8 \\
\hline Total & 27 & 29 \\
\hline
\end{tabular}

(Wultiple responses possible)

A Excludes membership in ECO.

$B$ Includes membership in ECO. Also includes 4 couples ( 8 respondents) whose spouse belonged to ECO and was included in the study.

The mean number of organizations in addition to ECO to 
which respondents belong is 1.4 . Their spouses belong to a mean of 1.6 organizations including ECO. Ten of the "active" ECO members' spouses do have organizational affiliations. It should be noted, however, that 8 of those 10 are also included as respondents in the study.

With reference to Payne et al., the broad area of Interpersonal Roles and Experiences will now be considered. Influences of significant others is the first category proposed. Because of later definitions of relations with family, friends, etc., the influences of those connected with occupation and those in positions of community leadership will be the only topics studied here. The following table shows the attitudes held by significant others at the "active" ECO member's place of occupation.

TABLE XIV

"ACTIVE" ECO MEMBERS' PERCEPTIONS OF CO-WORKERS' VIEWS ABOUT THOSE MEMBERS' PARTICIPATION IN ECO

\begin{tabular}{|lc|}
\hline $\begin{array}{l}\text { How do the people where you work } \\
\text { view your participation in ECO? }\end{array}$ & $\begin{array}{l}\text { Number of } \\
\text { Respondents ( } f \text { ) }\end{array}$ \\
\hline $\begin{array}{l}\text { They encourage my community involvement } \\
\text { in general. }\end{array}$ & 5 \\
$\begin{array}{l}\text { They neither encourage nor discourage } \\
\text { my activities. }\end{array}$ & 2 \\
They are unaware of my participation. & 3 \\
They nave not expressed any feelings. & 1 \\
Does not apply (not employed). & 9 \\
\hline
\end{tabular}


or those employed, $45 \%$ ( 5 respondents) perceive encouragement to participate by the people where they work. Co-workers are seen by 55\% ( 6 respondents) as being neutral with regard to participation in ECO by the respondent. No members percelved criticism or discouragement from coworkers .

The following table presents an indication of how those interviewed think that local government officials view ECO.

TABLE XV

"ACTIVE" ECO MEMBERS' VIEWS CONCERNING THE PERCEPTIONS OF "LOCAL" GOVERNMENT OFFICIALS ABOUT ECO

\begin{tabular}{|lcc|}
\hline $\begin{array}{l}\text { How local government } \\
\text { officials view ECO }\end{array}$ & $\begin{array}{c}\text { Number of Respondents } \\
(f)\end{array}$ & $\begin{array}{c}\text { Percent } \\
(\%)\end{array}$ \\
\hline $\begin{array}{l}\text { They have a "wait-and-see" } \\
\text { atti tude }\end{array}$ & 12 & $60 \%$ \\
$\begin{array}{l}\text { They are hopeful that ECO } \\
\text { will achieve its goals }\end{array}$ & 6 & $30 \%$ \\
No opinion & 2 & $10 \%$ \\
\hline & 20 & $100 \%$ \\
\hline
\end{tabular}

A neutral "walt-and-see" stance is seen by $60 \%$ of the respondents with $30 \%$ indicating that the officials have a somewhat more optimistic view of the organization.

The other variable of interpersonal roles proposed by Payne et al. Includes informal relations with a variety of people including friends and family. 
The following table indicates the attitudes which the "active" ECO members perceive as being held by their families concerning the participation of those members.

TABLE XVI

FAMILY ATTITUDES TOWARDS "ACTIVE" ECO MEMBER'S PARTICIPATION

\begin{tabular}{|c|c|}
\hline Attitude & Number of Respondents ( $f$ ) \\
\hline \multicolumn{2}{|l|}{$\begin{array}{l}\text { How does your family view your } \\
\text { participation? }\end{array}$} \\
\hline $\begin{array}{l}\text { They encourage my community } \\
\text { involvement in general. }\end{array}$ & 10 \\
\hline $\begin{array}{l}\text { They are especially interested } \\
\text { in my work with this particular } \\
\text { group. }\end{array}$ & 4 \\
\hline $\begin{array}{l}\text { They neither encourage nor } \\
\text { discourage my activities. }\end{array}$ & 4 \\
\hline They discourage my activities. & 1 \\
\hline Does not apply. & 1 \\
\hline $\begin{array}{l}\text { Does your family resent the } \\
\text { time you spend relative to ECO? }\end{array}$ & \\
\hline Definitely & 2 \\
\hline Somewhat & 6 \\
\hline No & 6 \\
\hline Absolutely not & 5 \\
\hline Does not apply & 1 \\
\hline
\end{tabular}

(Horizontal lines indicate separate questions) 
In general, respondents see their families as being clearly supportive of involvement in ECO. While 70\% (14 respondents) indicate this approval, $40 \%$ ( 8 respondents) believe that to some degree their families may resent the amount of time and energy spent by the ECO participant.

The next table indicates the relationship between "active" ECO participants' friends and the organization. 
TABLE XVII

"ACTIVE" ECO MEMBERS' PRIENDSHIP RELATIONS

RELATIVE TO ECO

\begin{tabular}{|c|c|}
\hline Item & Number of Respondents $(f)$ \\
\hline \multicolumn{2}{|l|}{$\begin{array}{l}\text { How many people in ECo did } \\
\text { you know before you Joined } \\
\text { the group? }\end{array}$} \\
\hline $\begin{array}{l}\text { Less then } 10 \% \\
10 \% \\
25 \% \\
50 \%\end{array}$ & $\begin{array}{l}8 \\
4 \\
3 \\
5\end{array}$ \\
\hline \multicolumn{2}{|l|}{$\begin{array}{l}\text { Have your friends joined ECO } \\
\text { at your suggestion? }\end{array}$} \\
\hline $\begin{array}{l}\text { Yes } \\
\text { No }\end{array}$ & $\begin{array}{l}10 \\
10\end{array}$ \\
\hline \multicolumn{2}{|l|}{$\begin{array}{l}\text { How do your friends view } \\
\text { your participation in ECO? }\end{array}$} \\
\hline $\begin{array}{l}\text { They encourage my } \\
\text { community involvement } \\
\text { in general }\end{array}$ & 3 \\
\hline $\begin{array}{l}\text { They are especially } \\
\text { interested in my work } \\
\text { with this particular }\end{array}$ & \\
\hline group & 3 \\
\hline $\begin{array}{l}\text { They neither encourage } \\
\text { nor discourage my } \\
\text { activities }\end{array}$ & 12 \\
\hline $\begin{array}{l}\text { They have not expressed } \\
\text { any feelings }\end{array}$ & 2 \\
\hline $\begin{array}{l}\text { I jolned ECO because a friend } \\
\text { invited me. } \\
\text { (Response to an open-ended } \\
\text { question) }\end{array}$ & 2 \\
\hline
\end{tabular}

Frlends of those surveyed seem to be perceived as neutral or supportive of the respondent's participation in 
ECO, and $50 \%(10)$ of the participants had friends who joined at their suggestion. Eight of the respondents (40\%) knew more than $10 \%$ of those in the group when they first joined. This brings us to the final issue for consideration advanced by Payne et al.: Residential Mobility and Length of Time Resident in a Given Community. The following table shows the residential mobility of the respondents.

\section{TABIE XVIII}

LENGTH OP RESIDENCE IN CURRENT HOME OF "ACTIVE" ECO MEMBERS

\begin{tabular}{|cc|}
\hline Length of Residence & Number of Respondents $(f)$ \\
\hline t year & 3 \\
1 year & 4 \\
2 years & 3 \\
3 years & 2 \\
4 years & 1 \\
5 years & 1 \\
6 years & 3 \\
7 years & 3 \\
\hline Total & 20 \\
\hline
\end{tabular}

only 6 respondents (30\%) stated that they had moved since coming to the Evergreen area. The mean length of residence in current homes was 3.3 years, exactly year less than the mean length of residence in the Evergreen area. Length of time which respondents have resided in the Evergreen area is indicated in the next table. 
TABLE XIX

LENGTH OF RESIDENCE IN THE EVERGREEN AREA OP "ACTIVE" ECO MEMBERS

\begin{tabular}{|c|c|c|}
\hline Years in Evergreen & $\begin{array}{l}\text { Number of Respondents } \\
(\mathrm{f})\end{array}$ & $\begin{array}{l}\text { Percent } \\
(\%)\end{array}$ \\
\hline $\begin{array}{l}\text { More than } 1 \text { year but } \\
\text { less than } 2 \text { years }\end{array}$ & 6 & $30 \%$ \\
\hline 2 years & 3 & $15 \%$ \\
\hline 3 years & 1 & $5 \%$ \\
\hline 4 years & 2 & $10 \%$ \\
\hline \multicolumn{3}{|l|}{5 years } \\
\hline 6 years & 4 & $20 \%$ \\
\hline 7 years & 4 & $20 \%$ \\
\hline Total & 20 & $100 \%$ \\
\hline
\end{tabular}

No participant had been in the area less than 1 year or more than 7 years when interviewed. The mean length of residence is 3.8 years.

A somewhat different measure of "moblitty" relating to the ties within one's community is the location of occupation. In a primarily residential and non-industrial area such as Evergreen this is especially relevant. The following table indicates the place of employment of both "active" ECO members and their spouses. 
TABLE XX

PLACE OF EMPLOYMENT OF "ACTIVE" ECO MEMBERS AND THEIR SPOUSES

\begin{tabular}{|lcc|}
\hline Place of Employment & $\begin{array}{c}\text { Number of } \\
\text { Respondents ( } f)\end{array}$ & $\begin{array}{c}\text { Number of } \\
\text { Spouses }(f)\end{array}$ \\
\hline Evergreen & 6 & 3 \\
Vancouver & 1 & 3 \\
Elsewhere in Clark County & 1 & 2 \\
Portland area & 3 & 5 \\
Large area in Washington & 0 & 1 \\
and Oregon & 9 & 4 \\
Does not apply & 20 & 18 \\
\hline \multicolumn{2}{|c}{ Total } & \\
\hline
\end{tabular}

of the respondents surveyed, $40 \%$ ( 8 respondents) are employed in Evergreen, Vancouver, and the rest of Clark County, as are $44 \%(8)$ of their spouses. Employment in the Portland area 18 held by $15 \%$ (3) of the respondents and $28 \%$ (5) of their spouses. Only $30 \%(6)$ of the interviewees and 17\% (3) of their spouses are actually employed in the Evergreen area itself. The table indicates that $25 \%$ (5) of the respondents and $61 \%$ (11) of their spouses leave the Evergreen area for their jobs. (No attempt was made in thts table to consider responses of the married couples in which both members were interviewed. There are 8 persons, then, who appear in both colums of the chart simultaneously.) 
Attention is now turned to the areas of attitude and motivation. In reviewing the literature, several studies were concerned with attitudes affecting participation. Some dealt in specifics such as satisfaction with the group, degree of influence, etc. Others addressed the issue of community concern and homogeneity of attitudes. Before discussing data relative to these areas, however, information concerning participation level in ECO by the respondents will be examined. The following table summarizes the participation efforts expended by the population interviewed.

TABLE XXI

PARTICIPATION OF "ACTIVE" ECO MEMBERS IN ECO

\begin{tabular}{|lc|}
\hline Participation & Number of Respondents ( $\mathrm{f})$ \\
\hline Members perceived degree of their & 11 \\
own activity in ECO & 6 \\
Very active & 3 \\
Moderately active & 8 \\
Not very active & 5 \\
Committee membership & 7 \\
Boundary committee & \\
Communication committee & 7 \\
Questionnaire committee & 13 \\
\hline Held a formal office in ECO & \\
Yes & \\
No & \\
\hline
\end{tabular}

(Horizontal lines indicate separate question)

By the time the interview was given, $15 \%$ of those defined as "active" considered themselves as "not very 
active." Formal offices in ECO were held in the spring of 1975 by $35 \%$ (7) of those surveyed. The "active" members were falrly evenly divided in their committee participation. The questionnaire committee was the largest and the communication committee the smallest in terms of total membership.

Length of time which the population had been active in community activities is presented in the following table.

TABLE XXII

LENGTH OF COMMUNITY ACTIVITY OF "ACTIVE" ECO MEMBERS

\begin{tabular}{|ccc|}
\hline Lenoth of Activity & Number of Respondents (f) & Percent \\
\hline & & \\
Less than 1 year & 4 & $20 \%$ \\
1 to 3 years & 3 & $15 \%$ \\
3 to 6 years & 5 & $25 \%$ \\
6 years or more & 8 & $40 \%$ \\
\hline Total & 20 & $100 \%$ \\
\hline
\end{tabular}

Being "active" in groups such as ECO is typlcal for $80 \%$ (16) of those interviewed. Indeed, 65\% (13 respondents) have been active for 3 years or more, and $40 \%$ have been active for 6 years or longer.

Attention will now be given to the area of attitudes contributing to participation. The following table summarizes the decisions made by "active" ECO members relative to initial participation and to continuing "active" status. 
TABLE XXIII

DECISIONS TO PARTICIPATE AND DO SO ON AN ACTIVE BASIS MADE BY "ACTIVE" ECO MEMBERS

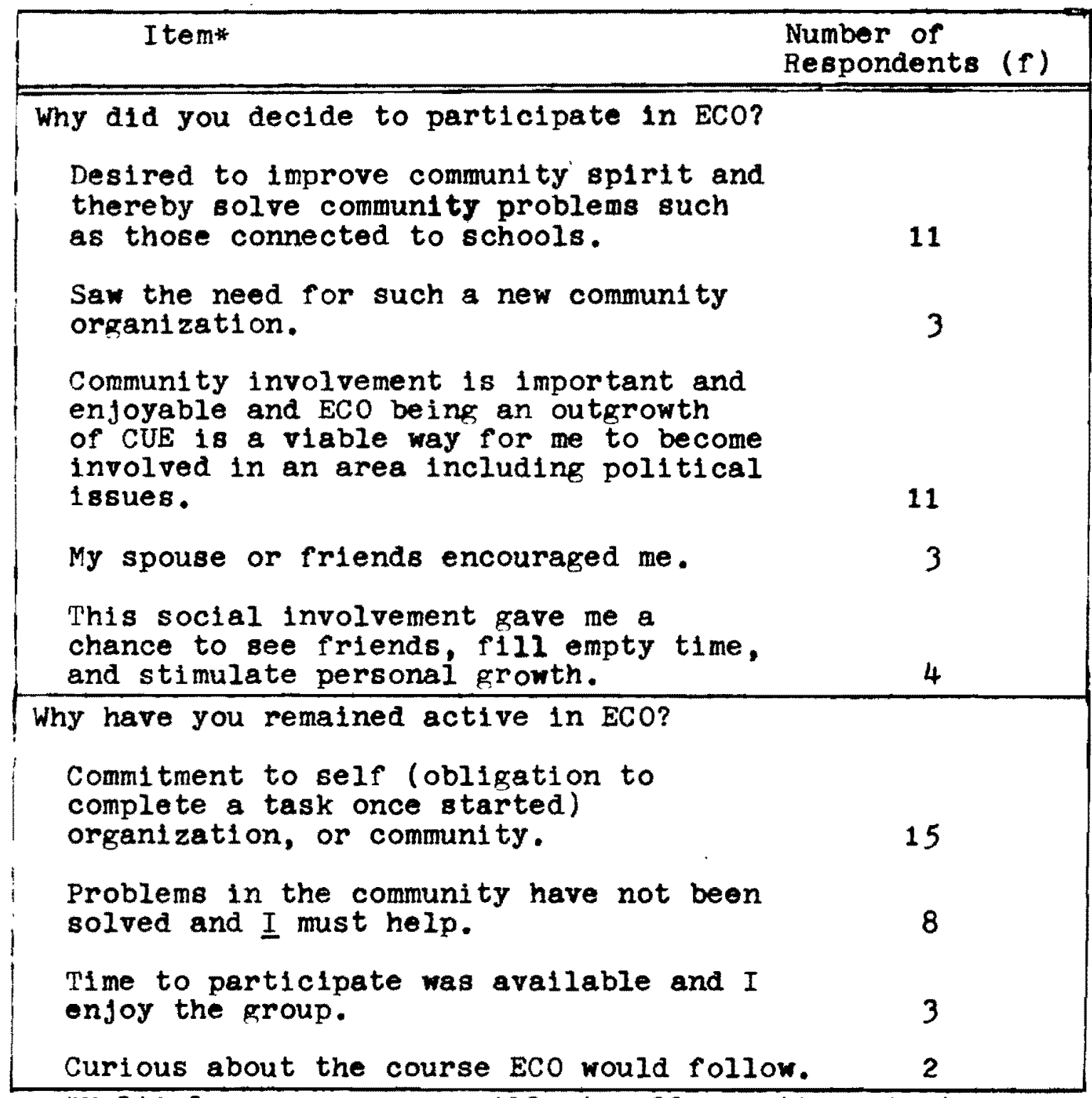

* Multiple responses possible to all questions in this table.

(Horizontal lines indicate separate questions) 
Over half of the participants indicated that they Joined ECO in order to help solve community problems and believed that this organization was a viable means to do so. of those interviewed, $75 \%$ (15 participants) continue to participate out of a sense of obligation, and $40 \%$ ( 8 participants) think that the problems in the community have not yet been solved.

Participants were asked whether they expected to learn anything from their participation in ECO, and $90 \%$ (18 respondents) indicated having had that expectation. The following table indicates what, if anything, interviewees hoped to learn by participating in ECO.

\section{TABLE XXIV}

WHAT "ACTIVE" ECO MEMBERS HOPED TO LEARN BY PARTICIPATING IN ECO

\begin{tabular}{|lc|}
\hline Knowledge & $\begin{array}{c}\text { Number of } \\
\text { Respondents (f) }\end{array}$ \\
\hline $\begin{array}{l}\text { The manner in which community } \\
\text { organizations are established and function. }\end{array}$ \\
Increased knowledge about the community \\
itself including the political structure, \\
others' perceptions of the problems, etc. \\
No knowledge gain expected.
\end{tabular}

(Multiple responses possible)

More information about the community itself was the main area of interest with $70 \%$ (14 respondents) indicating that category. 
The following table indicates the relationship which respondents saw between ECO participation and their job.

IABLE XXV

"ACTIVE" ECO MEMBERS' YERCEPTIONS OF CO-WORKERS' VIEWS OF THOSE MEMBERS' PARTICIPATION IN ECO

\begin{tabular}{|lc|}
\hline Item & $\begin{array}{c}\text { Number of } \\
\text { Respondents (f) }\end{array}$ \\
\hline $\begin{array}{c}\text { Is Eco participation helpful to you in } \\
\text { your job or career? (including homemaking) }\end{array}$ & 13 \\
No & 7 \\
How will participation in ECo help your \\
job or career?* \\
Skilis learned and people met will \\
increase the volume of my business or \\
my effectiveness in my occupation. \\
Self improvement leads to being more \\
effective in other phases of life \\
(including work). \\
There is political value in knowing the \\
"right" people. \\
This relates to other skilis in my role \\
as a professional volunteer. \\
No help (see preceeding item).
\end{tabular}

Multiple responses possible for this question.

(Horizontal lines indicate separate question).

of those interviewed, $65 \%$ ( 13 respondents) believed that ECO would be helpful in their job or career. Most of these respondents saw participation in ECO as being helpful in terms of development of self-improvement ski11s. Some related the expected gains to the development of concrete skilis which would increase their effectiveness in meeting 
people and allow them to increase the volume of their business.

Relative to the areas of satisfaction with the organization and amount of influence in the group, the following table is presented.

TABLE XXVI

"ACTIVE" ECO MEMBERS' PERCEPTIONS OP

THE DECISION MAKING PROCESS OCCURRING IN ECO

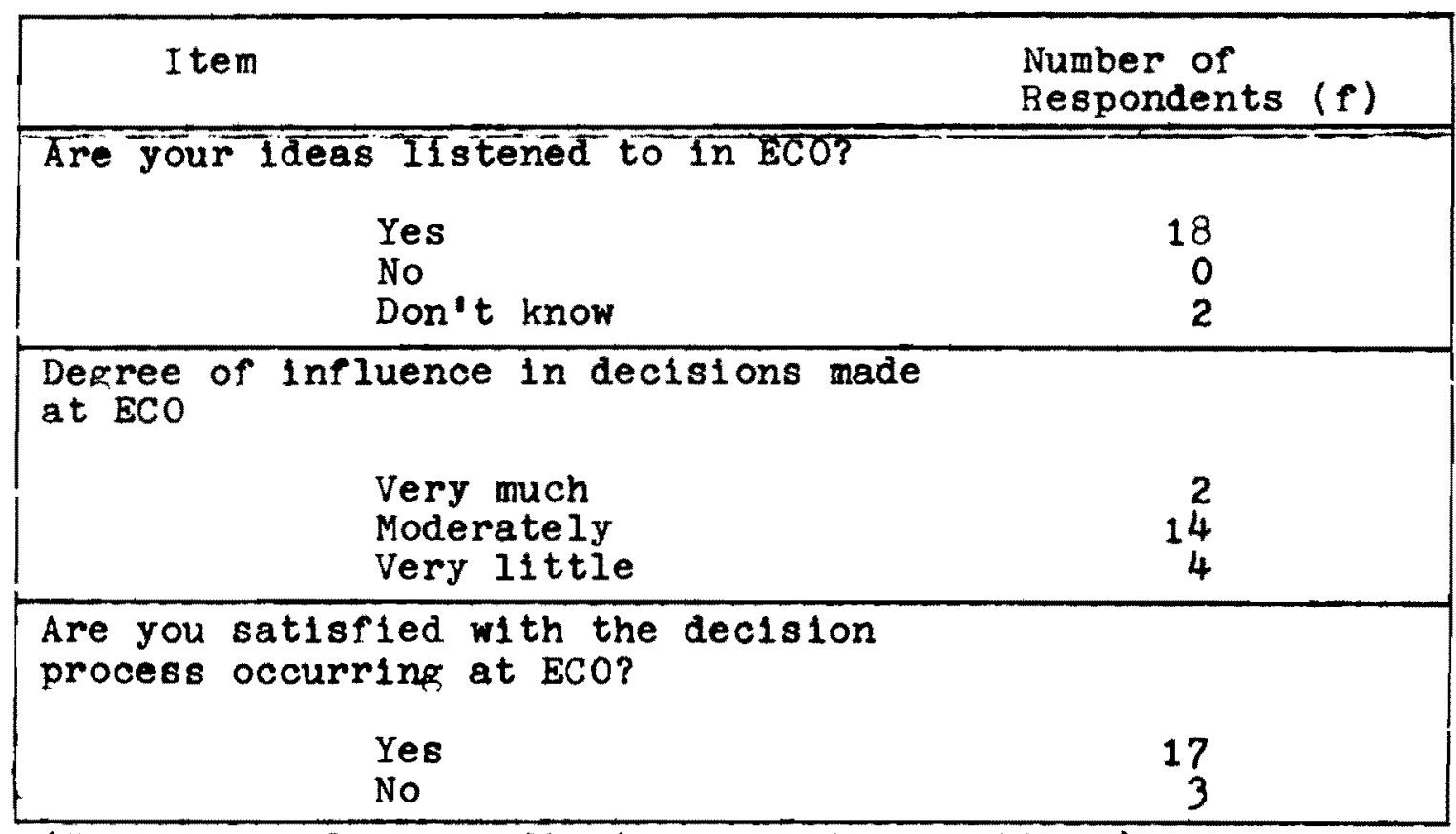

(Horizontal lines indicate separate questions)

Note that $85 \%$ ( 17 respondents) are satisfied with the decision making process. Of those interviewed, 90\% (18 respondents) believe that their ideas are listened to, although only $10 \%$ ( 2 respondents) think that they have a great deal of influence. A moderate amount of influence is 
perceived by 70\% ( 14 respondents), however, $20 \%$ ( 4 respondents) perceive themselves as having very little influence. Satisfaction with the role of the professional consultants from the University of Washington is summarized in the following table.

TABLE XXVII

"ACTIVE" ECO MEMBERS ' VIEWS OF THE UNIVERSITY OF WASHINGTON CONSULTANTS' ACTIVITIES

\begin{tabular}{|cc|}
\hline Item & $\begin{array}{c}\text { Number of } \\
\text { Respondents ( } f \text { ) }\end{array}$ \\
\hline How well did the University of Washington \\
consultants serve ECO? \\
Very well \\
Tairly well & 11 \\
OK & 5 \\
Fairly poorly & 2 \\
Very poorly & 0 \\
No opinion & 1 \\
\hline What kind and degree of guidance should & \\
the consultants provide in the future? & \\
Nore & 2 \\
Same & 18 \\
Less & 0 \\
\hline
\end{tabular}

(Horizontal lines indicate separate questions)

Some degree of satisfaction was indicated by $90 \%$ (18) of the respondents. The same proportion indicated that the same kind and degree of guidance should be provided by the consultants in the future.

Turning to another area, degree of community concern has been studied as a variable influencing participation in 
groups such as ECO. The following table indicates the participant's personal community concern.

TABLE XXVIII

"ACTIVE" ECO MEMBER'S DEGREE OF CONCERN WITH COMMUNITY PROBLEMS

\begin{tabular}{|c|c|c|c|c|c|c|c|}
\hline $\begin{array}{r}\text { Level of Co } \\
\text { (possible scor } \\
\text { from } 23 \text { to } \\
\end{array}$ & $\begin{array}{l}\text { nce } \\
\text { es } \\
69\end{array}$ & $\begin{array}{l}m_{m} \\
\text { ran }\end{array}$ & & & & & $\begin{array}{l}\text { Number of } \\
\text { Respondents } \\
\text { (f) }\end{array}$ \\
\hline $\begin{array}{l}63 \\
62 \\
61 \\
60 \\
59 \\
58 \\
57 \\
56 \\
55 \\
54 \\
53 \\
52 \\
51 \\
50 \\
49 \\
48 \\
47 \\
46\end{array}$ & 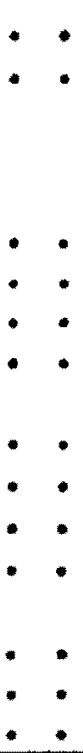 & $\begin{array}{l}: \\
: \\
: \\
: \\
: \\
:\end{array}$ & : & : & : & : & 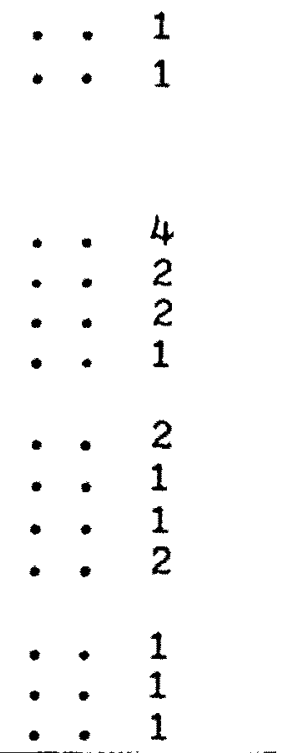 \\
\hline \multicolumn{5}{|c|}{ Total } & \multicolumn{3}{|r|}{20} \\
\hline
\end{tabular}

The respondents ranked 23 community problems in terms of their personal concern with the issues. "Very important" items received 3 points, problems "of some importance" received 2 points, and issues "of little importance" received 1 point. (See also Table XXIX.) Scores would range from a possible highest concern of 69 points to least concern at 23 points for each individual respondent. The mean score in this question is 47.3 . As a measure of relativity, a 
respondent choosing "of some importance" on all 1 tems would score 46.

The issue of homogeneity of attitude could be discussed in relation to several tables already presented. Nevertheless, 3 final tables will be included here to illustrate this point. These issues also deal with community concern. Table XXIX indicates the relative importance of community problems as perceived by the interviowees. 
TABLE XXIX

RELATIVE IMPORTANCE OF COMMUNITY ISSUES

AS PERCEIVED BY "ACTIVE" ECO MEMBERS

\begin{tabular}{|c|c|c|c|c|}
\hline \multirow[b]{2}{*}{ Issue* } & \multicolumn{3}{|c|}{$\begin{array}{l}\text { Number of Respondents } \\
\text { selecting oach degree of } \\
\text { concern }\end{array}$} & \multirow{2}{*}{$\begin{array}{l}\text { Total Score } \\
\text { (possible } \\
\text { scores } \\
\text { range from } \\
20 \text { to } 60 \text { ) }\end{array}$} \\
\hline & $\begin{array}{c}3 \\
\text { Very } \\
\text { Important }\end{array}$ & $\begin{array}{c}\text { Of }^{2} \text { Some } \\
\text { Impor tance }\end{array}$ & $\begin{array}{l}1 \\
\text { Of Littie } \\
\text { Importance }\end{array}$ & \\
\hline $\begin{array}{l}\text { Schools } \\
\text { Community Spirit } \\
\text { Land Use } \\
\text { Tax Base } \\
\text { Ecology \& Environ. } \\
\text { Parks \& Recreation } \\
\text { State \& Local News } \\
\text { Availability } \\
\text { Law Enforcement \& } \\
\text { Corrections } \\
\text { Garbage \& Waste } \\
\text { Disposal } \\
\text { Industrial-Bus. } \\
\text { Base } \\
\text { Health Services- } \\
\text { Medical \& Dental } \\
\text { Mental Hlth. Servs. } \\
\text { Land Values } \\
\text { Street Improvement } \\
\text { \& Construction } \\
\text { Juvenile Services } \\
\text { Water Supply \& } \\
\text { Rates } \\
\text { Drug \& Alcohol } \\
\text { Abuse Treatment } \\
\text { Child Care } \\
\text { Handicapped Servs. } \\
\text { Employment \& Job } \\
\text { Training } \\
\text { Housing Needs } \\
\text { Geriatrics and } \\
\text { Nursing Homes } \\
\text { Sewers }\end{array}$ & $\begin{array}{l}19 \\
18 \\
17 \\
16 \\
16 \\
13 \\
12\end{array}$ & $\begin{array}{r}6 \\
11 \\
7 \\
11 \\
9 \\
11\end{array}$ & $\begin{array}{l}3 \\
2 \\
3 \\
2\end{array}$ & $\begin{array}{l}59 \\
58 \\
57 \\
56 \\
56 \\
53 \\
52 \\
50 \\
50\end{array}$ \\
\hline & & & Mean Scor & 47.3 \\
\hline
\end{tabular}

* Issues listed in order of ranked importance 
The highest possible score which an issue could recelve is 20 ; the lowest, 60 . As a measure of relativity, an issue scored "of some importance" by all respondents would recelve a score of 40 . Only 4 issues scored less than 40,2 ranked at 40 , and 17 received higher scores, the highest being 59 which is very close to the maximum possible. The mean score for this question as stated earlier is 47.3 . Homogeneity of attitude is seen most clearly in the issues rates as most important. Agreement decreases as importance of issues decreases.

The next table presents the areas seen by respondents as the main problem in the Evergreen area.

TABLE XXX

EVERGREEN'S "MAIN PROBLEM" AS IDENTIFIED

BY "ACTIVE" ECO MEMBERS

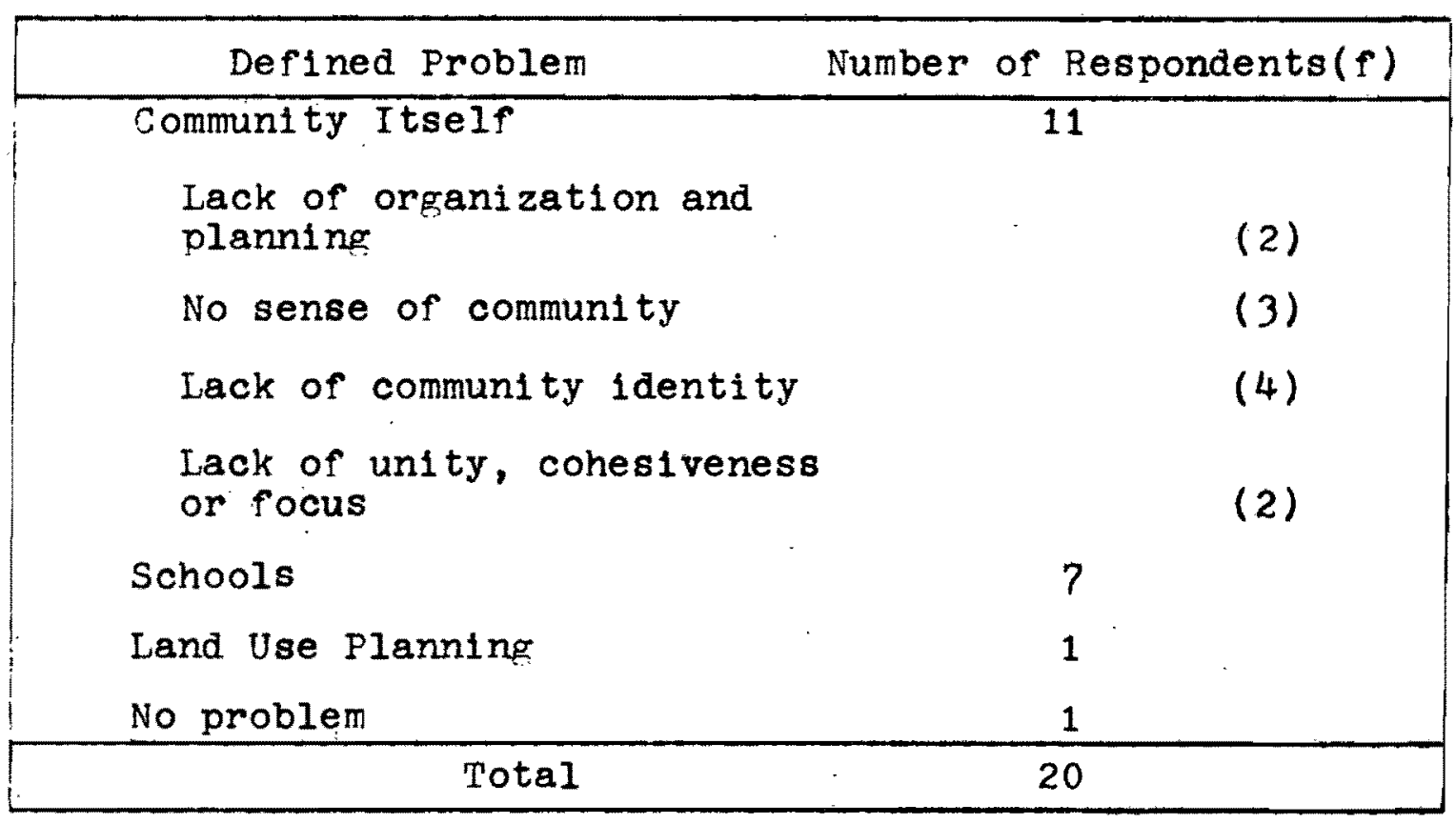


Community identity and awareness is mentioned by 55\% (11 respondents), and 35\% ( 7 respondents) indicate schools as the focal issue in the communtty. There is little disagreement in this area-few alternatives were even mentioned.

The final table prioritizes the projects which the respondents would like to have ECO undertake.

TABLE XXXI

"ACTIVE" ECO MEMBERS' PRIORITIZING OF PROJECTS

WHICH THEY WOULD LIKE ECO TO UNDERTAKE

Project topic area (listed in order of preference)

Points

Schools

40

Land use and planning 32

Increase tax base by inviting clean industry 18

Adequate services (utilities)

Creation of community group to decide issues and help run the community, do long range planning, etc.

Public services (libraries, parks, recreation, etc.) 11 Governmental organization of the county

Social services

Other (miscellaneous 2nd and 3rd cholces of individual respondents)

Interviewees were asked to indicate in an open ended question what 3 projects they would like ECO to work on in order of preference. The responses were assigned 5 points 
for first cholce, 3 points for second choice, and 1 point for third choice. Points were then totaled, the highest possible score being 95. While it is not readily apparent how well individual respondents agreed in this table, it 1s apparent that schools are seen as the greatest problem area. Both the issues of schools and the issue of land use and planning were mentioned in first, second, or third place by $50 \%$ of the population and were separated by a wide gap in scores from any other topics.

This chapter has presented the data gathered from the interviews with the research population of "active" ECO members. The data was organized following the conceptual framework introduced in the review of literature and further developed by the authors. Discussion of the results and their relationship to other research will be presented in another section of this study. 
CHAPTER V

\section{AMPLIFICATIONS AND INTERPRETATIONS}

This study is directed toward examination of some sociodemographic and attitudinal variables related to participation in ECO by its "active" members. The rindings of the study will be amplified and discussed in terms of the relationships between those findings and the findings of other studies as presented in the review of the 11terature. In addition, some interpretations of the findings will be presented with regard to the effect of the characteriatics of the "active" members upon the organization's composition and activity. The question of degree of relative homogeneity of members' characteristics and attitudes will be considered in relationship to the data and to the ilterature presented. Sociodemographic characteristics of members will be considered first. The initial component of sociodemographic factors is that of "Life Cycle Stage" and age is the first variable considered in this component. The findings showed that "active" ECO members mean age is 37 , which conforms to the general findings (cited in the review of literature) that peak levels of participation occur in the middle $401 \mathrm{~s}$, plus or minus 10 years. Only 3 members are in the 20 's age range, and these are all in the upper 20 's which conforms to Argyle's (1959), Schuyler's (1959), and W1lensky's (1961) 
findings that voluntary organization participation rates are sharply lowered in the 20-30 age range. It should be noted that the mean age of 37 places most members within the childrearing stage of the life cycle.

Marital status is the next component of life cycle stage. All members of the population studied have been married and $90 \%$ are presently married, with one member being separated and one member being divorced. The studies cited in the revieu of 11 terature indicate that higher rates of both membership and participation in voluntary organizations are exhibited by married persons than by those who are widowed, separated, or divorced. This population conforms to that pattern. Furthermore, this population includes fewer divorced persons than might be expected, given current divorce rates for the general population. This population exhibits a generally high level of current marital stability, and marital stability appears to be a factor predisposing individuals to participation in voluntary associations, as noted by Hunter and Maurice (1953), Bell and Force (1956a) and others cited previously.

Babchuk and Gordon (1962) found that a positive relationship exists between being unmarried and the assumption of leadership roles within voluntary organizations. The findings of this study of ECO members are consistent with those of Babchuk and Gordon in that the one unmarried member of the research population is the president of the organization. 
Number of children is the next factor under consideration. The findings in the literature indicate that, in general, participation levels increase with number of children. However, membership tends to decline when number of children exceeds two. Participation is most likely when a parent has one or two children. The findings in this study with regard to this variable are inconclusive; $40 \%$ of the population have either one or two children, only $5 \%$ (one member) has no children. The remaining 55\% have more than two children (See Table I).

Age of chlldren is the next area of social background factors related to participation. The major finding reviewed here is that, in general, having all children of school age favors higher membership and participation rates (Schmidt and Rohrer, 1956; Lazerwitz, 1961; Spiro, 1968; and Harry, 1970). Of the 45 children of "active" ECO members, only four are under age six. Most children (32) are in the school-age range of 6 to 19, with 9 children from three families being in the age range of 19 to 28 . With this population, "active" participation is definitely associated with members' having all children of school-age. This factor appears to be related to later findings that schools and education are primary issues of concern that mobilize this population to participate in voluntary activity in the Evergreen community.

These four variables make up the constellation of factors called "Iife cycle stage" by Payne et al. It is 
apparent that the population of "active" ECO members conforms to the general nature of the findings with regard to age, marital status, number of children, and age of children as these variables affect participation in a voluntary organization.

Socioeconomic status is the next sociodemographic factor to be considered and it includes sereral variables addressed by this study and by the literature reviewed. The first of these variables is that of income. As noted in the presentation of results (Table V), the mean annual family income of "active" ECO members is $\$ 17,500$, a solidly middleclass income figure. The population is relatively homogenous with regard to income, with no members considered to be "low income" (there is no respondent with family income under $\$ 10,000$ ) and none in the "wealthy" category (no one over $\$ 29,999)$. The fact that most ECO members are middle class with respect to income may also be related to higher educational and occupational status. Studies cited in the review of literature uphold the finding that higher income is associated with greater levels of participation in voluntary organizations. An interesting relationship between income and participation in voluntary organizations is suggested by Payne et al., who note that participation in voluntary organizations may be a way of increasing income indirectly by allowing opportunity to make contacts with prospective customers, clients, and associates. Thirteen "active" ECO 
members (65\%) believe that participation in ECO would help them in their job or career. These respondents believe that ECO participation will help them to enhance work-related skills and the meeting of people that would lead to increased career opportunities and, presumably, higher income (see Table XXV).

Education is the second variable of socioeconomic status considered by this study. The findings indicate a well-educated population which includes no persons with less than a high school education. Table VI shows that $55 \%$ of the "active" ECO members are at least college graduates, with $40 \%$ of respondents having done work beyond the Bachelor's degree level; $95 \%$ of the respondents have some education beyond high school. The findings in the literature indicate that participation in voluntary organizations is strongly related to level of education, and higher levels of education are associated with higher levels of involvement. This population appears to conform to that general finding. Smith (1972) summarizes the research on education and voluntary association participation by stating that more educated people participate because of greater ability to understand and be committed to abstract organizational goals, greater understanding of organizational operation, and greater selfconfidence and social confidence. ECO's goals of "increasing community spirit, involvement, and identity" cortainly fit the criteria of abstraction which well-educated people are 
able to understand and function with relatively comfortably. These factors, together with reflections of feelings of self-confidence and social confidence, are well-1llustrated in Table XXIII.

Another issue addressed in the review of 11 terature with respect to education levels of participants is that of differences in the types of organizations to which people belong as a function of the extent of formal education. The studies cited indicate that people with more education participate more in professional, business, civic, educational, cultural, social service, and political groups. In other words, people with more education become involved in issueoriented or cause-oriented voluntarism. As 1llustrated in Table XIII, the "active" members of ECO hold a number of memberships in other community civic and service organizations. The concern with community issues and problems appears to be positively related to membership and active participation in ECO.

Occupational status is another component of socioeconomic status. Of "active" ECO members, $50 \%$ have professional level jobs. Of these ten people, seven are involved in education as either teachers, administrators, or professional-level support personnel. Of the remaining 10 members of the population, 9 ( $45 \%$ of the total population) are housewives. One member works as a skilled tradesperson, and he is attending college in order to provide himself with the educational potential for upward occupational mobility. 
With regard to spouses' occupational level, $45 \%$ of the married members of the population have spouses employed in education or other professions, and $22 \%$ of members' spouses are housewives. The remaining $33 \%$ of spouses are employed as skilled laborers or salespersons. Relating these findings to the literature, it is apparent that the relatively high level of occupational status evidenced by this population is related to the higher rates of participation among highly educated persons that have been found in various studies, as cited in the review of literature. The high proportion of people with occupational ties to education tends to emphasize that schools are a major concern in the Evergreen community.

The high proportion of housewives in ECO is noteworthy when considered in relationship to the cited study by Slater (1960), in which the researcher found that in the upper middle class, the role of "wife" appears to be more compatible with voluntary group membership than it does in the working class, where the role of "wife" is more likely to include conflicts between housework and active voluntary group membership. The fact that ECO has so many "active" members who are housewives is a further indication of 1 ts middle-class character as an organization.

Payne et al. note that middle-class persons are expected, by virtue of their occupational roles, to have more formal voluntary organization memberships than do persons in other socioeconomic classes. Because organtzations provide occupational and professional development 
opportunities, participation becomes a means of vertical occupational and social mobility.

Home ownership is the final component of socioeconomic status addressed in the discussion of social background factors. or the twenty respondents, eighteen (90\%) own or are buying their homes. Several studies cited in the review of literature found home ownership to be related to higher rates of membership and participation in voluntary associations, and this population conforms to that general pattern. It is likely that home owmership is a central component of the upper middle-class, suburban characteristics of this population in the Evergreen community.

Payne et al. see home ownership as being related to length of residence in the community as a significant factor influencing participation in the voluntary organization. Given the finding (see Table XIX) that no "active" ECO member has lived in the Evergreen community for more than seven years, Evergreen can be seen as a relatively mobile community. Other measures of mobility were presented in this study, including a question on length of residence in present home. The mean length of residence in present home was found to be 3.3 years, also indicating a relatively high degree of community mobility. The study also indicated that only $30 \%$ of respondents work within the Evergreen community, indicating a high degree of mobility into and out of the area each working day. 
The third major cluster of social background factors includes the variables of sex and race. Of the population of "active" ECO members, $65 \%$ are women and $35 \%$ are men. The findings in the literature indicate that this relationship may be a product of relatively recent social change and may be a result of Increasing education for women, the impact of the women's movement, and other social changes. Women have previously been found to participate in voluntary organizations less often than do men, and findings have indicated that participation by women is generally in religlous or service-oriented voluntarism. The authors speculate that participation in ECO by such a large number of women is a function of high education, need for fulfillment outside the home, and concern with education as a key issue addressed by ECO in the Evergreen community.

The fact that all ECO members are white appears to be a reflection of the fact that the community is oreruhelmingly white in composition. Clark County has a very small proportion of non-white residents, most of whom live in urban Vancouver rather than in the suburban Evergreen area. The fourth component of sociodemographic characteristics with, which this study is concerned is what Payne et al. term "formal organizational affiliations and roles." The first varlable consldered here is that of religion. The population under study is overwhelmingly Protestant. There are no Catholics in the population (see Table IX). This 
finding conforms to general findings that Protestants join civic and service organizations at a higher rate than do Catholics (Hausknecht, 1962). Also, Catholics have been found to have lower non-religious voluntary group participation than do members of other religious groups, as mentioned in the review of ilterature.

Political affiliation is another variable to be considered here. The fact that all respondents are registered voters and have voted in an election within the past year indicates that this population 18 more politically active than the general population (see Table X), as does the fact that $65 \%$ have helped to circulate an initiative or petition within the past two years. Of the population studied, $60 \%$ have campaigned actively for a candidate within the past four years. As noted in the findings, most of these candidates were running for local offlce, indicating that local politics are important to "active" ECO members. The fact that $80 \%$ of the population attended some kind of public meeting within the past year (see Table XII) is further indication of the high level of political activity engaged in by members of this group. Payne et al. point out that several studies have found that political activity $1 B$, in general, found to be associated with membership and partic1pation in non-political voluntary associations. Devereux (1960) found that those whose level of particlpation in voluntary organization is high tend to be identified with the community and interested in local and national affairs. The 
material presented in Tables $X, X I$, and $X I I$ indicates that "active" ECO members follow this pattern of interest in local and national affairs.

The last category of organizationsl affiliations and roles includes the variable of membership in multiple formal organizations. As noted earlier, this group is quite active in other organizations. The results presented in Table XIII indicate that $85 \%$ of "active" ECO members belong to some community or service organization other than ECO, and $70 \%$ belong to other community organizations in the Evergreen community (CUE is the major other organization to which ECO members belong). This item did not address the issue of respondents' activities in other kinds of formal organizations.

The fifth major cluster of sociodemographic factors includes the dimension entitled "interpersonal roles and experiences" in the analysis by Payne et al. As noted earlier, Table XXV indicates that a number of respondents believe that participation in ECO will help them to develop self-improvement skills, interpersonal skills, and political contacts which will help them to increase their effectiveness in their job or career. Table XVI addresses the variable of family attitudes toward members' participation in ECO. It is emphasized that of the twenty members studied, there are four married couples. In addition, one member joined primarily at the urging of her spouse, who himself is not active in 
the organization. The studies by Anderson (1946), Babchuk (1965), and others note that spouses are especially influential on each other's membership and participatory roles in settings where both spouses are participating. This mutual influence seems to be a factor operating within the population under study. A related aspect of interpersonal influences on participation is demonstrated by the finding that $70 \%$ of the population have families whom they see as encouraging participation in the organization, while $20 \%$ of families are seen as neutral, and only $10 \%$ are belleved by the respondents to oppose their participation. This finding indicates a high level of percelved family support for community involvement by the members surveyed.

It $1 \mathrm{~s}$ of interest to the researchers that only $40 \%$ of the respondents knew more than $10 \%$ of those in ECO when they first joined the organization. Whether this finding indicates lack of motivation from friends to join or is a function of the moblilty of the area is open to question. About $50 \%$ of the respondents had friends join the organization at their suggestion, which is probably a significantly higher proportion of people able to engage in effective recruiting than might be exhibited by the general membership of ECO. The size of the organization was decreasing at the time of the interviews, so this figure might indicate a degree of leadership (possessed by the "active" members who were staying with the group) that is not possessed by the other members not defined as "active" for purposes of this study. 
The population of "active" ECO members is composed of persons who are generally seen as being community leaders. The elected offlcers, therefore, were necessary for the parliamentary functioning of the organization but, in fact, provided little more direct leadership than many of the "active" members who were not officers.

Length of residence in the communtty has been studied by several researchers with regard to its effect on participation in voluntary organizations. Payne et al. point out that length of residence is an important variable since it may have a direct influence on social relationships. The newcomer lags behind the longer-term residents in establishing social relations and jointing local groups to which they are attracted. Some of the indicators of moblilty in Evergreen were discussed earlier in this chapter, such as the findings that the mean length of community residence is 3.3 years, and $60 \%$ of the respondents have lived in the cormunity less than five years. The studies by Kaufman (1949), Zimmer (1955,1956), Babchuk and Thompson (1962), Spiro (1968) and others indicate that lower rates of participation in voluntary associations may be expected during the first five years of residence in a community. This organization seems to have problems holding a large membership, and it is somewhat more understandable when examined in the $11 \mathrm{ght}$ of the research that has been done upon the adverse effect of high community mobility upon organization membership and participation. 
The remainder of the findings to be discussed relate to the attitudes and motivations of the membership with regard to their decisions to participate and to remain active in the organization and to their attitudes toward participation in ECO and toward the organization itself. Table XXI indicates the perceived degree of activity expended by members of ECO in the organization. As Table XXI indicates, 11 members (55\%) said that they were "very active," 6 members (30\%) said they were "moderately active," and 3 members (15\%) said they were "not very active" in the organization. If the interviews had been done closer to the time that the sample was drawn, the number of members expressing the opinion that they had been "very active" might have been higher. However, as time elapsed and the character of the organization changed, members' perceptions of their degree of activity, as well as their actual level of activity, changed. Respondents' comments indicate that the nature of the organization was changing character, not that the population held inaccurate perceptions of their own participation.

Table XXIII indicates findings relative to decisions made by respondents to participate actively in ECO. The first two response categories in that table indicate a feeling held by respondents that a community organization such as ECO is necessary to provide for improvement of community spirit and solutions to Evergreen community problems. As 
studies by Downing (1957) and scott (1953) show, attitudes indicating a feeling of necessity for the existence of a specific voluntary organization are correlated with participation in that organization. Forty-four percent of the total number of responses to the item "Why did you decide to participate in ECO?" Indicated the need for an organization to address specific community concerns and issues. Smith (1966) indicated that the "perceived efficacy of the specific organization to achieve its goals" is a significant variable influencing members to participate. It is this "percelved efficacy" of ECO to improve community spirit and solve community problems that seems to be a major factor motivating the population under study to participate in the organization.

Fifty-four percent of the total number of responses to the item "Why have you remained active in ECO?" indicated a feeling by respondents of commitment to themselves and to the community. One respondent, whose feelings reflected those of many in the population, stated: "The needs of the community were the same as when I joined and I st1ll belleved ECO was a good tool." As noted by Mulford and Klonglan in the review of literature, middle-class persons who participate in formal voluntary organizations do so because of their favorable attitudes toward the community and a sense of obligation to the community. It is this degree of commitment that influenced many members of ECO to begin 
to participate in ECO and to continue participation once started. Smith (1966) discusses the attitudes of "commitment to the organization" and "felt obligation to participate in the organization" as being two highly significant factors motivating and sustaining participation. The response of another member to this item illustrates the kind of feelings attached to decisions to participate and to continue participation. She said, "My personality is such that once I start something I don't drop 1t. I don't let specific events or personalities deter me." Studies cited in the review of literature, including studies by W1lson (1954), Freeman et al. (1957), and Jesser (1967) support the strone relationship between voluntary organization activity and attitudes indicative of a personal sense of general commitment to organized voluntary activity and/or to the community. Th1s relationship appears to be an important factor influencing participation by members of ECO.

The feeling by many ECO members that they have an "obligation to finish something they've started"can be seen as a "commitment to self" that is related to general middleclass values embodying a strong "work-ethic" component. This feeling of need to complete a project, to feel goaloriented and task-oriented, and to stay with a task or goal until completion is reached is a component of motivation that might be expected from a middle class population such as that which composes ECO. It is apparent from the responses 
that this population holds these general values with regard. to participation in this organization.

A related issue is that of use of the organization by a minority of individuals (generally housewives) as a means of promoting personal growth by getting out of the house and into contact with people and ideas beyond their own homes. A few of the housewives responded to the question regarding why they participated in ECO by pointing out that the role of housentfe engenders some feelings of boredom and some empty time, which these women cope with by becoming involved in voluntary associations in the community. This activity may also fulfill a felt need to contribute to or participato in the community of which these women are members. The very nature of the role of "housewife" provides little opportunity to affect the community in ways other than voluntary organization participation.

Another factor found to be somewhat influential in motivating participation includes the responses by three members that their spouse or friends encouraged them to participate. Smith's (1966) research found the influence of significant others to be a key influence upon voluntary organization participation. This influence is seen as moderately affecting participation in ECO.

To summarize the preceding section, it is userul to point out that Mulford and Klonglan view "effectiveness of the organization" as being a variable associated with members' 
attitudes regarding participation. There were no questions in the interview schedule regarding organizational effectiveness. However, most members seemed to feel that organizational effectiveness depends upon degree of participation. They see ECO as a potentially effective tool for bullding community spirit and initiating problem-solving, and the view seems to be that participation must come first and that organtzational effectiveness will follow from intial and sustained participation by people.

Table XXVI presents findings related to members' perceptions about their own effectiveness in the organization and their satisfaction with the group's decision-making processes. As noted in the review of 11 terature, Likert (1961) found that active and effective organizations are characterized by members who feel that they have influence in the organtzation. Smith and Brown's (1964) pindings were similar. Beal's (1956) study emphasized the importance to level of participation of members' feelings of ability to "have a say" in the running of the organization. It is apparent from examining Table XXVI that most members feel that they have at least a moderate degree of influence in the organization and that their ideas are listened to by other members. One member responded, "Yes, I feel accepted," when asked if her ldeas were listened to, a response which indicates a relationship between feeling accepted and having influence in the group. 
Three persons ( $15 \%$ of the population) stated that they were not satisfled with the decision-making process in the organization. Two respondents felt that the process is haphazard, inefficient, and lacking in stmucture, and they expressed discomfort with this situation. Another respondent was critical of herself, stating that she feels unsophisticated in expressing her 1deas and therefore feels that others do not listen to her. The overall level of satisfaction, however, with the processes of decision-making in the organization appears to be fairly high among the active members studied.

One issue studied with regard to members' attitudes toward participation in ECO was that of opinions of the consultation given to ECO by the consultants from the University of Washington's Division of Community Development. In general, as shown in Table XXVII, the level of satisfaction among members regarding the quality of the consultation is high, with $55 \%$ of members rating the quality as "very good," an additional $25 \%$ rating 1 t as "fairly good." of the population of "active" members, $90 \%$ felt that the consultation should continue at the same level in the organization's future. Responses of the two individuals who were dissatisfied with the kind of consultation given the organization are included here. One respondent stated that:

The consultants should have been more prepared and listened to what we had to say. They should have IIstened to us when we told them how many people we could get involved in doing the survey. They (the 
consultants) gave us the feeling that the survey was not successful, when in terms of this community, I feel it was very successful. The consultants really used a poor psychological approach.

The other less than fully satisfied respondent stated:

They should have provided more technical and logistical information. They should have given us more options to choose from. If they had presented several models we could have chosen the best parts from all of them and combined them into something workable for our special situation. Instead they presented us with the way it was going to be done and more or less rammed it down our throats. They should have given us more choices so we could have put together a better program.

These criticisms of the consultation from the Division of Community Development are congruent with some research findings about the Division's program as it relates to ECO. A 1970 study published in the Community Development Journal found that the University of Washington Division of Community Development program has problems with the approach to community leadership. Relying on community initiative and using self-help, learn-while-you-do-it techniques, together with the non-directiveness of the consultant, combine to produce un-satisfactory results. The study goss on to point out that the voluntary involvement of people in a lengthy and community-wide development program seems to be too large a burden, with the result being that the "burn-out" rate of citizens is high over the "long haul." The study recommends, among other things, that: (1) the action phase be initiated earlier and operate concurrently with the study phase, (2) an ongolng community development program should 
be introduced, and (3) a formal system of evaluation be introduced. Nevertheless, $90 \%$ of the "active" ECO members were satisfied with the consultation.

The fact that "burn-out" is a problem with ECO is illustrated by the high rate of attrition that occurred in the first three to five months of the organization's iffe. It is the opinion of the researchers that the length of the program is a factor associated with this attrition. The researchers concur with the above mentioned recommendations that the action phase be initiated earlier in the course of the program. It is apparent from the data that the "active" members of ECO see Evergreen as a community with problems that need to be solved through community development. It is also apparent that the large majority of these people see the consultation given to the organization as being helpful in meeting the goals of the organization. It is possible that part of the attrition from the organization can be attributed to feelings about the consultation given to the organization, but that issue is beyond the scope of the present research. Some recommendations which address the issue of the consultation given by the Division of Community Development will be presented later in this discussion. Another issue addressed in this study is that of members' degree of concern with community problems as a possible motivating factor in their decisions to intiate and sustain participation in the organization. As noted earlier, 
research has shown that there is a strong relationship between feeling of identification with the community and participation in voluntary organizations. Table XXVIII Indicates that respondents had "some concern" in general about community problems in terms of how important these community issues were to their own lives. The fact that these items were not rated as being of "very much concern" may indicate that, although the population may view these items as being important issues for the community, the specific issues do not have as much impact on the lives of the individuals studied. The distinction is an interesting one because it might indicate that people are able, in this instance, to see community concerns as separate and distinct from their own lives. This feeling was expressed by interviewees who stated (with variations), "Well, this item is very important to the community, but it is actually of little importance to me."

Table XXIX indicates the relative importance of each community issue to members of the population. The table shows that the most important issues are: (1) Schools and Education, (2) Community Spirit and Involvement, (3) Land Use, (4) Tax Base, and (5) Avallability of State and Local News. The issue of avallability of state and local news is a major issue in Clark County because of its proximity to the Portland metropolitan area and the resulting coverage of oregon news in the area. There are no television stations 
and very few radio stations in Vancouver, with the primary Washington state and local news coverage coming from the Columbian, Vancouver's only dally newspaper. The fact that television news is primarily oriented to oregon news, plus the fact that The Columbian is the only medium which consistently carries news from the state of Washington, tends to help to engender a homogeneity of attitudes toward Washington state politics.

The fact that these five issues are identified as the most important community concerns may result from the interrelationship of Evergreen's position as a new, rather amorphous community, the problems of Washington's methods of school funding, and the struggle to balance the needs for land use, adequate tax base, and adequate school system. The citizens of Evergreen, and particularly the members of ECO, view these problems in a unique way and seem to hold relatively homogenous attitudes about the high priority of these issues. As noted in the review of literature, studies by Tannenbaum and Backman (1966) and Sm1th (1967) have indicated that uniformity or homogeneity of attitudes 18 one aspect of what Smith calls "groupness" and that those who are most active in a voluntary association are likely to hold such uniform attitudes. This homogeneity of attitude regarding the most pressing problems of the Evergreen community characterizes the population of "active" members of ECO. It seems that the interest in community issues and 
problems may be related to the educational and occupational characteristics of this population. The feelings of obligation to serve and of commitment to the community may be part of a general orientation to work and to continued upward mobility typical of members of the "successful" middle class Dopulation of a suburban area with sienificant community problems. Given the formulation that the social characteristics and attitudes of this group of people have predisposed them to participate in such an organization, the question arises as to why other residents of the Evergreen community, with similar social characteristics, have not chosen to participate in this organization. Why have only twenty persons chosen to become "active" in this community group dedicated to the study of community problems and to political and social changes directed at developing solutions to these problems? The answers to these questions are beyond the scope of this study. However, it is posstble to discuss some possible issues related to the question.

The study indicates that this group of persons is remarkably homogenous in terms of attitudes about the community, about its significant problems and their solutions, and about participation in voluntary organizations in general and ECO in particular. For example, there is general agreement about the purposes of the organization, its priority projects, and the kind and degree of consultation it should recelve from the University of Washington's Division of Community 
Development. Also, the members of ECO are in close agreement about the nature of Evergreen's problems and their possible solutions, as the findings indicate. This homogeneity of attitudes, as well as of sociodemographic characteristics, has been found in other studies to characterize voluntary association participants, as indicated in the review of Iiterature.

It is likely that an organization such as ECO needs members that are relatively homogenous with regard to sociodemographic and attitudinal variables, since the instrumental purposes of the organization require general agreement about goals and methods employed by this particular community development program. There are probably more than twenty persons in the Evergreen community with sociodemographic characteristics similar to those possessed by the "active" ECO membership. In a community with a population of more than 30,000 persons, there are probably others with similar attitudes about the problems of the community and their solutions. To verify these speculations would require research beyond the scope of the present study. However, the relevant generalization seems to be that, of the elghty to one hundred persons who began to participate in ECO, these twenty possessed a certain combination of social characteristics and attitudes about themselves, about the community, about voluntary association participation, and about the purposes and policies of the Community Development Division 
of the University of Washington. Even more important, perhaps, are the feelings of apreement about the priorities of problems and their possible solutions.

It seems likely, therefore, that this particular combination of relatively homogenous sociodemographic and attitudinal characteristics helped to motivate this population to participate in this particular voluntary organization at this time. Given the finding that ECO's membership is relatively homogenous with respect to sociodemographic and attitudinal characteristics, and given the findings that many such organizations do have members with homogenous characteristics, is it reasonable to expect that persons with widely varying social characteristics and attitudes can or should be recruited to join an organization like ECO? It seems likely that many of the eighty to one hundred residents present at the first two meetings of ECO perceived themselves to be out of fit with either (1) the purposes of the community development program, (2) the necessary attitudes toward the community. (1ts issues or problems), or toward themselves, or (3) the general sociodemographic characteristics that usually accompany active membership in a voluntary organization such as ECO. The Implications of this hypothesis for the organization will be discussed later.

Referring again to Table XXIX, it is interesting to note that some of the items which this population sees as being of little importance (sewers, fuvenile services, services for the handicapped) are services which Clark County 
and Washington state officials have been working to provide in recent years. For example, county juvenile officials have been trying to obtain bond approval to build a new juvenile detention facility for Clark County. For several, years, this effort has met with little success.

The fact that employment and job training is rated as a concern near the bottom of the list is testimony to the fact that none of ECO's members are unemployed, another indication of the relative economic stability characterizing this middle-class population. Geriatrics is not seen as a problem, probably because in this group of people with a median age in the middle 30 's, most members have not yet experienced having an aged parent's needs to content with. Also, no member of the population is over 50 , so aging is not a personal issue yet for these people. Housing needs are seen as being of some importance by most respondents. This may be due to the high mobility in the area, creating situations where people may have just bought a home or may be thinking of selling their present home.

Table XXX further indicates the homogeneity of attitudes possessed by members of the population. The table is concerned with the answers presented to the question "When you joined ECO, what was Evergreen's main problem?" In response to this item, issues related to problems of community identity are seen by 55\% of respondents as Evergreen's main problem. Schools are seen by $35 \%$ as the main problem of the community. 
Land use planning, as in Table XXIX, is seen as the main problem by one of the respondents. The fact that the two issues of community identity and schools are reversed here might be explained by the difference in emphasis between Items 22 and 23 of the interview schedule. Item 23 asked how important various community issues were to the respondent. Item 22 asked, in effect, what was the most 1mportant issue to the Evergreen community. The respondents see identity as the main problem of the community, but the main community problem as it affects their lives (and the life of their family) is that of schools.

The respondents who identify the "community 1 tself" as the main problem area for the community see several main components of the problem. Two respondents see what they term a "lack of organization and planning" in the community's growth to date. Three respondents termed the problem "no sense of community," while four respondents commented on the "lack of community identity," two response categories which seem to be similar, if not identical. Two more respondents saw a "lack of unity, cohesiveness, or focus." An example of these responses is: "Evergreen is not a community in terms of common goals or identity."

Table XXI indicates the priorities of projects which the "active" members would like ECO to undertake. The three highest priority projects are (1) schools, (2) land use, and (3) increasing the tax base by attracting "clean, light industry" to the area. A possible reason why "community 
spirit" is not among the prioritized projects may be that the respondents see "community spirit" as a more abstract, less tangible kind of goal than are the 1ssues of improved school financing and development of an adequate tax base. "Community spirit" may be seen as a goal that becomes a rather nebulous item when seeking to develop a project for an organization to undertake. Furthermore, members probably perceive community spirit and involvement to be a condition which would begin to develop as the community begins to identify and work on more concrete, specific projects.

The interrelationship of the school finance problem, the tax base problem, and the problem of land use and planning is again demonstrated by the high ranking of these three items as community concerns. Another area which elicited a relatively high degree of interest as a project was that of insuring adequate public services. In this category, respondents included such services as roads, sidewalks, sewers, drainage, garbage, police, fire, and lighting (not prioritized). Table XXXI indicates that "adequate services" rankB equally with "increase tax base" as a priority project. However, a larger total number of respondents (8) are concerned with tax base than are those (6) who are concerned with adequate services.

The final topic for consideration here is the last item on the interview schedule, which invited respondents to make any desired comments on the interview topics or about 
the organization. Of the twenty respondents, seven made no comment. One respondent stated: "I feel that my neighbors are negative about my involvement. They suspect that I have ulterior motives." This respondent seems to be concerned that others will see participation in ECO as a way of advancing political gain within the community.

A general response made by several people to this itom was the feeling that more people should have become involved in ECO and taken part in its activities. Several respondents also expressed discouragement with the apathy toward community issues that they found in other people in the community. Some nembers of the population viewed the formation of ECO as being a positive step toward helping improve community spirit and identity.

In order to summarize the data gathered in this study, the following composite description of the "typical" ECO member was developed. It is recognized that such a description is a generalization of the large amount of data that has been presented and discussed, and that no such member exists in reality. However, such a generalization may be a useful way to summarize the findings of the study. The "typical" ECO member is a married woman living in the Crestline or Burton area of the Evergreen School District. She has three children, ages 18,13 , and 11 , and two of them are in the public schools. She and her husband have lived in the district almost four years, and moved into their present 
home, which they are buying, a little over three years ago.

This ECO member is 36 years old and is a housewife, with some college education. Her husband is employed in the Clark County area, has some education beyond high school, and is earning $\$ 17,500$ per year. Their religlous preference is Protestant, probably Methodist.

In the political area, the typical ECo member 18 fairly active. She is registered to vote and has voted in the past year. She is affiliated with a political party and in the past four years has helped to campalgn actively for two candidates, one of whom was a candidate for the school board. She has helped ofrculate initiatives or petitions in the past two years and has attended three to ten public meetings in the past year. At least one of these meeting was a school board meeting.

The typical ECO member considers herself to be moderately active in ECO, and is also a member of one other community or service organization, most likely CUE. She has been active in community organizations for about five years. Her husband, while not belonging to ECO, probably belongs to one similar organization, probably CUE.

Before this respondent joined ECO she knew $10 \%$ or less of those who have participated in the group. Her friends have nelther encouraged nor discouraged her participation, but her family encourages her community involvement in general and does not resent the time and energy which she spends participating in ECO. 
The ECO member joined ECO out of a desire to improve community spirit and identity and to help solve community problems. She felt that, in some way, her participation would broaden her perspective and make her a better person. When she joined, she hoped to learn what others in the community felt were the main needs of the community and what the facts were concerning these needs.

She sees the communty problems as centering on schools, community spirit and identity, and land use. If she could choose projects for ECO to work on, she would attack school problems first, land use and planning second, and attracting clean, light industry to improve the tax base, third.

The ECO member remains active in ECO because the problems of the community have not yet been solved and because of a sense of obligation to complete an activity once she starts 1t. She sees local government officials as taking a "wait and see" stance relative to $\mathrm{ECO}$, but she feels that they are basically supportive.

The decision-making process occurring at ECO is satisfactory to this respondent, and she feels that her ideas are listened to and taken into account by the group, although she feels that she only has a moderate amount of influence in the eroup. She thinks that the University of Washington consultants have served the group very well and that they should continue to provide the same kind and degree of 
guidance in the future.

In general, the active ECO member has a positive and even optimistic view of ECO. She states that more people have become involved already, although she continues to be discouraged by the general lack of interest in issues in the community. She feels that the organization is at a new starting point now and is hopeful that it will now progress into the study and action phases. 
CHAPTER VI

SUMMARY AND RECOMMENDATIONS

The Evergreen Community Organization has been in existence for slightly over a year at the time of this writing. The "active" members of the organization still form the basic nucleus of the group, with a few changes in membership. The characteristics of this "active" core of members have been studied and presented in this discussion.

This study began with the premise that the "active" members of the Evergreen Community Organization had certain characteristics which are definable and subject to study. The relevant characteristics under study were (1) sociodemographic characteristics of members, and (2) attitudinal factors with regard to self, significant others, the community, and the organization which motivate and sustain participation in ECO. The population of "active" ECO members was defined and a research instrument was drafted on the basis of previous research done in the field of voluntary association. The instrument was administered to the population, the results were tabulated, presented, and discussed in terms of their content, their relationship to previous research, and their implications for the organization under study. 
The single most striking general feature of the population of "active" ECO members with regard to their sociodemographic characteristics is their solidly middle-class nature. As indicated previously, the population is middleclass in terms of income, education, occupation, and interests. The data obtained in this study conforms in general to other research findings regarding social characteristics of members of formal voluntary organizations oriented to community service. The fact that this organization is an instrumental (goal and task oriented) community service organization makes it likely that well-educated, middle-income persons of high occupational status will participate to a greater extent than will members at either of the other extremes of the socioeconomic scale. Some of the reasons for differences in participation level between social classes were discussed in the review of literature, but a full development of theory concerning the reasons for differences in voluntary organization participation is beyond the scope of this study. This population does conform to the findings by other researchers that participation in such organizations generally comes from persons with the social characteristics found in the "active" members of this organization.

The attitudinal and motivational factors which induce individual participation in this organization and which sustain that participation once it is initiated provided the 
second focus for descriptive analysis with regard to the population of "active" ECO members. The most salient generalization about the population's attitudes and motivations to participate in this organization appears to be the presence of a general feeling of obligation to the community. This obligation seems to stem from several sources, including a significant degree of interest in community affairs, which includes political activity and membership in other voluntary organizations. The authors believe that the obligation to serve is also related to the possession of a significant amount of information about community issues and problems, and the subsequent formation of opinions about community needs. It seems likely that the factors which motivate participation are also the factors which sustain it. It is the opinion of the researchers that this study confirmed findings from other studies regarding soclodemographic and attitudinal characteristics of participants in community service oriented voluntary associations. It is also recognized that, since the study is unique to the Evergreen community, it focused upon events and activities unique to the community at this time. The findings, however, are $11 \mathrm{kely}$ to be especially applicable to community development organizations in other areas which face a perceived need for community development consultation and activity. Several issues were raised in this study which might have implications for the future course of this organization 
and for the community development program as conceived by the Community Development Division of the University of Washington. Some of these issues were introduced earlier in the description of the loss of membership experienced by ECO. The hypothesis that persons who dropped out of the organization did so because of their perceived lack of compatibility with the organization was discussed. Another possible reason for membership loss involves the problem of time available for participation. Some potential members may see themselves as fitting into the organization well, but may choose not to participate because they lack the time to do so. The remainder of the discussion will focus upon some recommendations that might be employed by the organization and its consultants in order to enhance the possibilities of attracting and holding members who do have the time to participate and contribute to the organization and its purposes.

Several possibilities exist for social action professionals or the membership of roluntary organizations when faced with a situation of loss of membership. The first possibility is to continue with the membership which remains loyal to the stated goals and programs of the organization. This possibility assumes that the goals and programs remain relatively stable over time and that the goals and programs can be accomplished with a relatively small group of people. Second, the organization can mount a recruiting drive in an 
attempt to involve persons with diversified social characteristics and attitudes about the community. Third, the organization can undertake a recruiting drive aimed at persons in the community with social characteristics and attitudes similar to those of the existing membership. Fourth, the organization can modify its goals or programs in an attempt to attract new members.

It is possible to evaluate these alternatives in view of the findings of this study and those reviewed in the literature. The first alternative expressed above appears to be the course that the organization is currently following. The original community development program is proceeding, and the active core of members is basically the same group as was identified as active in the spring of 1975, with only a few changes in membership. Since the study indicated basic satisfaction among "active" members with the organization's goals and concepts, the alternative of continuing with this core of "active" members is a reasonable one. However, several members commented upon the need for broader involvement in the organization in order to accomplish the goals of community development and beginning to find solutions to community problems, especially the creation of community spirit, identity, and solidarity, which are high priority goals.

The program as outlined by the consultants has the goal of involvement of as many persons as possible in the community 
development process, which was one important goal of the "community-wide survey" given by the organization in October 1975. Assuming that a maximally successful program of community development by this organization is desired; and assuming that such a program depends upon involvement of more people, the organization and 1 ts consultants need to consider the alternatives presented above.

The second alternative includes the possibility of undertaking a drive to involve a broader and more representative group of community residents in ECo's activities. Given the research which demonstrates the high degree of homogeneity of this population, such an alternative needs to be examined in terms of the effects upon the organization that could result from the introduction of members with sociodemographic and attitudinal characteristics different than those of the present "active" members. It may be that an organization such as ECO is unable to maintain itself as an organization if a more heterogenous membership is engaged in participation. It may also be that such an infusion of heterogeneity is what the organization most needs at this stage of development.

The third alternative open to the membership and the consultants is to increase membership by recruiting members with sociodemographic and attitudinal characteristics similar to those of the present membership. It seems that such an effort is a necessary first step in attempting to build a 
more solid, cohesive organization. In the opinion of the authors, the problems of the Evergreen area have not changed materially since the Evergreen Community Organization was formed. If ECO is to remain a viable organization, it needs to seek a larger, more widespread membership of community people. However, it is the opinion of the researchers that the fourth alternative needs to be considered.

The fourth alternative includes the possibility of modification of the goals or program of the organization in an attempt to attract new members. The researchers concur with several of the recommendations of court in his evaluation of the University of Washington's Community Development Division published in the Community Development Journal. This evaluation cited the problems of reliance on community initiative and "self-help" and the non-directiveness of the consultants as combining to produce non-satisfactory results. Also, the lengthy nature of the program tends to produce citizen "burn-out," causing loss of membership over the "long haul." As noted previously, that study recommends that the action phase be initiated earlier and operate concurrently with the study phase. The present researchers concur with that recommendation. First, it is felt that such a step would help to attract members who are interested in taking more immediate action on community problems. While the emphasis of ECO upon study of problems is important and indeed crucial to an ongoing program of community development, 
it is felt by the researchers that the severity of problems as identified by the "active" members warrants an emphasis upon action in conjuction with study on the part of the organization. It is felt that the more deliberate pace of ECO's activities is perceived by potential members as being detrimental to the taking of immediate action to solve immediate problems.

The recommendations of the researchers are based upon the findings about the attitudes and sociodemographic characteristics of this population of "active" ECO members. These recommendations include: (1) Initiate programs of action concurrently with study of community problems. Effective social work or community action practice often depends upon taking the data avallable, making an attempt at intervention, and assessing the intervention results before attempting further action. It is felt by the researchers that if ECO were to become a strong, action-oriented organization, the result would be increased efficiency in the use of avallable power, much of which is now concentrated on taking care of 1 mmediate community problems in a fragmented, haphazard fashion. (2) Initiate recruiting programs that will identify and attract potential members to the organization. It seems necessary to first recruit more members who share the sociodemographic and attitudinal characteristics of the present members, in order to build a more stable organizational base of relatively homogenous members. It may be that succesful 
community development in Evergreen will depend upon a broader, more heterogenous movement and upon a correspondingly broader membership in ECO. However, it is premature to attempt to develop such an organization or movement until the present organization has a larger, more stable, relatively homogenous membersh1p base.

It is the opinion of the authors that the voluntary association of citizens represents a useful, viable method of communtty development. More research is needed to concentrate upon (1) how to meaningfully involve citizens in an effective program of community development through voluntary association, and (2) what kinds of consultation from social workers, planners, and other human service and community development professionals will be most useful to the organlzation of citizens interested in community development. This study, together with other research examined in the review of literature, has presented a view of the kind of person who becomes involved in community action oriented voluntary associations. It is necessary for further practice and research to be directed toward fuller, more efficient utilization by professionals of the time and talents of persons involved in community action voluntary associations. This study will be concluded by quoting from a comment made by one of the "active" ECO members in response to the final item in the interview with the researchers. The respondent stated: "We've accomplished something and I feel 
good about it. We're at a beginntng point--the real work is yet to come..." 
SELECTED BIBLIOGRAPHY

Adams, Bert $N$, and James Butler

1967 "Occupational Status and Husband-Wife Soclal Participation." Social Porces 45 (June): 501-507.

Adams, Robert Lynn and John Mogey

1967 "Marriage, Membership and Mobility in Church and Sect." Sociological Analysis 28: 205-214.

Anderson, C. Arnold and Bryce Ryan

1943 "Social Participation Differences among Tenure Classes in a Prosperous Commercialized Farming Area." Rural Soc10logy 8: 281-90.

Anderson, Walfred $A$.

1938 The Membership of Farmers in New York Organizations. Ithaca, New York: Bul1. 695, ComeII Univ. Agric. Exper. Station.

1946 "Family Social Participation and Social Status SelfRatings." American Sociological Review 11: 253-58.

Argyle, Michael

1969 Religious Behavior. Glencoe, Illinois: The Free Press.

Axelrod, Morris

1956 "Urban Social Structure and Social Participation." American Sociological Review 21: 13-18.

Babchuk, Nicholas

1965 "Primary Friends and Kin: A Study of the Associations of Middle-Class Couples." Social Forces 43: 483-92.

Babchuk, Nicholas and $C$. Wayne Gordon

1962 The Voluntary Organization in the Slum. Lincoln, Neb.: University of Nebraska Studies, New Series no. 27.

Babchuk, Nicholas and Ralph V. Thomps on

1962 "The Voluntary Associations of Negroes." American Sociological Review 27: 647-55.

Baeumler, Walter L.

1965 Socialization Influences and Social Participation--A Study of Generational Continuity in Membership and Participation in Voluntary As8ociations. Unpublished Ph.D Dissertation. Lincoln, Neb.; University of Nebraska. 
Beal, George M.

1956" "Additional Hypotheses in Particlpation Research." Rural Soclology 21 (September-December): 249-56.

Be11, Howard M.

1938 Youth Teil Their Story. Washington, D.C.: American Counc1l on Education.

Be11, Wendell and Maryanne T. Force

1956a "Social Structure and Participation in Different Types of Pormal Associations." Social Forces 34: 345-50.

1956b "Urban Neighborhood Types and Participation in Formal Organizations." American Sociological Review 21: 2534 .

Booth, Alan and Nicholas Babchuk

1969 "Personal Influence Networks and Voluntary Association Affiliation." Sociological Inquiry 39: 179-88.

Brooks, Ralph M.; E. Walter Coward, Jr.; and George M. Beal

1969 "Some Effects of Intangible Goals on Extension Resource Development." Paper read at Rural Sociology Meetings, San Francisco.

Chapin, F. Stuart

1939 "Social Participation and Social Intelligence." American Sociological Review 4: 157-66.

Coleman, James S.

1961 The Adolescent Society. New York: Free Press.

Cooper, Homer Chassell

1961 "Perception of Subgroup Power and Intensity of Affiliation with a Large Organization." American Sociological Review 26 (Apri1): 272-74.

Copp, James $H$.

1964 "Perceptual Influences on Loyalty in a Farmer Cooperative." Rural Soclology 29 (June): 168-80.

Coser, Rose

1951 "Political Involvement and Interpersonal Relations." Psychiatry 14: 213-22.

Court, Michael

1970 "Problems in an Established Community Development Program." Community Development Joumal 5,4: 205-13. 
Cousens, F.R.

1964 "Indigenous Leadershtp in Two Lower Class Neighborhood Organizations." In Arthur B. Shostak and Wililam Gomberg (eds.), Blue Collar World. Englewood Cliffs, N.J.: Prentice-HaII.

Cowhig, James $D$, and Leo Schnore

1962 Religious Affiliation and Attendance in Metropolitan Centers," American Catholic Sociological Review 23(2): 113-27.

Dahl, Robert A.

1961 Who Governs? Democracy and Power in an American C1ty. New Haven: Yale University Press.

Davis, James A.

1961 Great Books and Small Groups. New York: The Free Press.

Devereux, Edward C.. Jr.

1960 "Community Participation and Leadership." Journal of Social Issues $16(4): 29-45$.

Downing, Joseph

1957 "Factors Affecting the Selective Use of a Social Club for the Aged." Journal of Gerontology 12 (January): $81-84$.

Erbe, William

1964 "Social Involvement and Political Activity: A Replication and Elaboration." Amertcan Sociological Review 29: $198-215$.

Foskett, John $M$.

1955 "Social Structure and Social Partictpation." American Soctological Review 20: 431-38.

Freedman, Ponald and Morris Axelrod

1952 "Who Belongs to What in a Great Hetropolis?" Adult Leadership $1: 6-9$.

Freeman, Howard E. ; Edwin Novak; and Leo G. Reeder

1957 "Correlates of Membership in Voluntary Associations." American Sociological Review 22 (October): 528-33.

Goldhamer, Herbert

1942 Some Factors Affecting Participation in Voluntary Associations. Unpublished Ph.D. dissertation. Chlcago: University of Chicago. 
Hagedorn, Robert and Sanford Labovitz

1967 "An Analys is of Community and Professional Participation." Social Forces 45(4): 483-91.

Harp, John

1959 "A reneral Theory of Social Participation." Rural Soctology 24 (September): 280-84.

Harp, John and Gordon J. Cummings

1968 "Discussion Groups and Public Affairs Education: and Analysis of Group Survival." Bulletin 70. Ithaca, New York: Department of Rural Sociology, Cornell University.

Harry, Joseph

1970 "Family Localism and Social Participation." American Journal of Sociology 75: 821-27.

Hastings, Philip $\mathrm{K}$.

1954 "The Non-Voter in 1952: A Study of Pittsfield, Massachusetts." Journal of Psychology 38: 301-12.

Hausknecht, Murray

1962 The Joiners: A Sociological Description of Voluntary Association Membership in the United States. Now York: The Bedminster Press.

1964 "The Blue-Collar Joiners." In Arthur B. Shostak and William Gomberg (eds.), Blue-Collar World. Englewood Cliffs, New Jersey: Prentice-Ha11, 207-15.

Hodge, Robert $W$. and David J. Treiman

1968 "Social Participation and Social Status." American Sociological Review 33: 722-40.

Hunter, W.W. and Helen Maurice

1953 Older People Tell Their Story. Ann Arbor: University of Michigan, Division of Gerontology.

Hyman, Herbert $H$, and Charles $\mathrm{A}$. Wright

1971 "Trends in Voluntary Association Membership of American Adults." American Sociological Review 36: 191-206.

Jacoby, Arthur $P$.

1966 "Personal Influence and Primary Relationships: Their Effect on Associational Membership." Sociological Quarterly 7:76-84.

Jesser, Clinton

1967 "Community Satisfaction Patterns of Professionals in Rural Areas." Rural Soctology 32 (March): 56-69. 
Jitodai, Ted

1965 "Urban-Rural Background and Formal Group Membership." Rural Soclology 30: 75-83.

Katz, Elihu and Paul F. Lazarsfeld

1955 Personal Influence: The Part played by People in the Flow of Mass Communications. Glencoe: Free Press.

Kaufman, Harold $P$.

1949 Participation in Organized Activities in Selected Kentucky Societies. Kentucky Agric. Bulletin 528.

Komarovsky, Mirra

1946 "The Voluntary Associations of Urban Dwellers." American Soclological Review 11: 686-98.

Larson, Richard $R$. and Catton, William $R$.

1961 "When does Agreement with Organizational Values Predict Behavior?" American Catholic Soclal Review 22: 151-160.

Lezerwitz, Bernard

1961 "Some Factors Associated with Variation in Church At tendance." Soclal Forces 39: 301-309.

1962 "National Data on Participation Rates Among Residential Belts in the United States." American Sociological Review 11: 686-98.

Likert, Rensis

1961 New Patterns of Management. New York: McGraw-Hill Book Company, Inc., 140-61.

Lynd, Robert $S$, and Helen M. Lynd

1929 Middletown. New York: Harcourt.

Maccoby, Herbert

1958 "The Differential Political Activity of Participants in

a Voluntary Organization." American Sociolog lcal Review

23: $524-32$.

Martin, Walter $T$.

1952 "A Consideration of Differences in the Extent and Location of Formal Associational Activities of RuralUrban Fringe Residents." American Sociological Review $17(6): 687-94$.

Mather, William $G$.

1941 "Income and Social Participation." American Sociological Review $6: 380-83$. 
Mayo, Selz C.

1950 "Age Profiles of Social Participation in Rural Areas of Wake County, S.C." Rural Sociology 15: 242-51.

Mulford, Charles Lee and Klonglan, Gerald E.

1972 "Attitude Determinants of Individual Participation in Organized Voluntary Action" in Voluntary Action Research: 1972. Smith, Reddy, and Baldwin (eds.) Lexington Books, Lexington, Mass.

Nelson, Merwyn; Verl R.W. Franz; and D.G. Marshall

1969 "The Franz-Marshall Scale of Commitment for Community Action". Rural Soclology 34 (September): 396-401.

Nolan, Francerra

1956 "Relationship of 'Status Groupings' to Differences in Participation." Rural Sociology 21: 298-302.

Orum, Anthony $M$.

1966 "A Reappraisal of the Social and Political Participation of Negroes." American Journal of Sociology 72 (1): $32-46$.

Olsen, Marvin

1970 "Social and Political Participation of Blacks." American Sociological Review 35: 682-97.

Payne, Barbara; Payne, Raymond; and Reddy, Richard D.

1972 "Social Background and Role Determinants of Individual Participation in Organized Voluntary Action." in Voluntary Action Research: 1972. Smith, Reddy, and Baldwin (eds.). Lexington Books. Lexington, Mass.

Phillips, Derek L.

1969 "Social Class, Social Participation, and Happiness: A Consideration of Interaction-Opportunities and

Investment." Sociological Quarterly 19 (Winter): 3-21.

Reid, Ira and E.L. Ehle

1950-51 "Leadership Selection in Urban Locality Areas." Public Opinion Quarterly, 14: 262-284.

Reissman, Leonard

1954 "Class, Leisure and Social Participation." American Soclological Review 19: 76-84.

Ross, Jack

1972 "Work and Formal Voluntary Organizations." Journal of Voluntary Action Research 1: 42-45. 
Schmidt, John $F$, and Wayne $C$. Rohrer

1956 "The Relationship of Family Type to Social Participation." Journal of Marriage and Family Living 18: $224-30$.

Schuyler, Joseph

1959 "Réligious Observance Differentials by Age and Sex in Northern Parish." American Catholic Soclological Review $20(2): 124-31$.

Schwirian, Kent $P$, and Margaret L. Helfrich

1968 "Economic Role and Communtty Involvement of Business Executives." Sociological Quarterly 9 (Winter): 64-72.

Scott, John C, Jr.

1957 "Membership and Participation in Voluntary Associations." American Sociological Review 22: 315-26.

Scott, William Abbott

1953 "Attitudes toward Participation in Civil Defense." Public Opinion Quarterly 17 (Fall): 374-85.

Sills, D.I.

1957 The Volunteers. Glencoe, Illinols: The Free Press.

Slater, Carol

1960 "Class Differences in Definition of Role and Membership in Voluntary Associations Among Urban Married Women." American Journal of Sociology $65(6): 616-19$.

Smith, glagett $G$. and Michael $E$. Brown

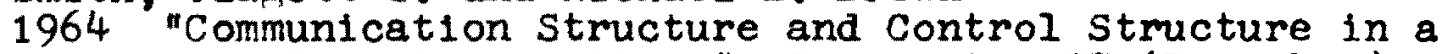
Voluntary Association." Sociometry 27 (December): 449-68.

Smith, David Horton

1966 "A Psychological Model of Individual Participation in Formal Voluntary Organizations: Application to Some Chilean Data." American Journal of Sociology 72 (November): 267-72.

1972 Research and Communication Needs in Voluntary Action. Occasional Papers: Center for a Voluntary Society. Washington, D.C.

1972 Voluntary Activity in Eight Massachusetts Towns. Draft. Institute of Human Sciences, Boston College.

Smith, David H.; Reddy, Richard D.; and Baldwin, Burt R. (eds) 1972 Voluntary Action Research: 1972. Lexington Books. D.C. Heath and Company; Lexington, Mass. 
Spinrad, William

1960 "Correlates of Trade Union Participation: A Summary of the Literature." American Sociological Review 25 (Apr11): $237-44$.

Spiro, Shimon E.

1968 Effects of Neighborhood Characteristics on Participation in Voluntary Associations. Unpubiished Ph.D. dissertation. Ann Arbor: University of Michigan.

Tannenbaum, Arnold S. and Jerald G. Backman

1966 "Attitude Uniformity and Role in Voluntary Organizations." Human Relations 19 (August): 309-22.

Uzzell, Odell

1953 "Institutional Membersh1p in Relation to Class Levels." Soclology and Social Research 390-95.

Warner, W. Keith and William D. Heffernan

1967 Benefit-participation Contingency in Voluntary Farm Organizations." Rural Soclology 32 (June): 139-53.

Warner, W. Lloyd and Paul S. Lunt

1941 The Social Life of a Modern Community. New Haven: Yale University Press.

Wilensky, Harold L.

1961 "Life Cycle, Work Situation, and Participation in Pormal Associations." In R.W. Kleemeler (ed.). Aging and Leisure. New York: Oxford University Press, 213-42.

Wilson, Everett $K$.

1954 "Determinants of Participation in Policy Formation in a College Community." Human Relations 7: 287-312.

Wright, Charles $\mathrm{R}$. and Herbert $\mathrm{H}$. Hyman

1958 "Voluntary Association Memberships of American Adults: Evidence from National Sample Surveys." American Sociological Review 23 (June): 284-94.

Zimmer, Basil G.

1955 "Participation of Migrants in Urban Structures." American Sociological Review 20 (2): 218-24.

1956 "Farm Background and Urban Participation." American Journal of Soc1ology 61: 470-75.

Zimmer, Basil G.

1959 "The Significance of Memberships in Association." American Journal of Sociology 65 (September): 196-201. 


\section{APPENDIX I}

\section{INTERVIEW SCHEDULE}

Date Circle respondent's sex $M F$

1. How long have you lived in the Evergreen area?

2. What elementary school area did you live in last spring?

3. How long have you lived in your present home?

4. Are you buying or renting your home? Buying Renting

5. What is your approximate age?

6. What is your marital status?

Single

Married

Separated

Divorced

widowed

7. Do you have any children? Yes

No

IP YES TO NUMBER 7--

8. How many?

9. What are the ages of your children?

10. Are any of them in the public schools? Yes

No 
IF YES TO NUMBER 10--

11. How many?

12. Are you employed .. . full time? , part time? no

13. What kind of work do (did) you do? (Include "housewlfe")

IF EMPLOYED --

14. What town or area do you work in?

15. How many years of education do you have?

No high school

Some high school

High school graduate

Trade or technical school

Some college

College graduate

Post college work

Master's degree

Law degree

Doctoral degree

16. What is your religious preference, if you have any?

I MARRIED--"I'D LIKE TO ASK SOME QUESTIONS ABOUT YOUR HUSBAND/WIFE NOW."

17. Is he/she employed.. full time? part time? no 
18. What kind of work does (did) he/she do?

(Include housewife)

IP EMPLOYED--

19. What town or area does he/she work in?

20. How many years of education does your husband/wife have?

No high school

Some high school

High school graduate

Trade or technical school

Some college

College graduate

Post college work

Master's degree

Law degree

Doctoral degree

(END OF QUESTIONS CONCERNING SPOUSE) 
21. Here is a card with some income figures on it. Please tell me the letter which corresponds to your total income (including yourself and your spouse).

Card given to respondent:

$$
\begin{aligned}
& \text { A. Under } \$ 10,000 \\
& \text { B. } \$ 10,000-\$ 14,999 \\
& \text { C. } \$ 15,000-\$ 19,999 \\
& \text { D. } \$ 20,000-\$ 24,999 \\
& \text { E. } \$ 25,000-\$ 29,999 \\
& \text { F. } \$ 30,000-\$ 34,999 \\
& \text { G. } \$ 35,000-\$ 39,999 \\
& \text { H. } \$ 40,000 \text { or more }
\end{aligned}
$$

22. When you joined ECO, if you could have chosen only one area, what would you have sald was Evergreen's main problem? 
23. Please rate the following items in terms of your own life at this time. (Give response card.). We are not concerned with how these issues impact the community but rather their importance to you as an individual. (Code no response as 0 )

Gerlatrics and nursing homes

Land values

Water supply and rates

Drug and alcohol abuse treatment

Mental health services

Law enforcement and corrections

Tax base

Ecology and the environment

Garbage and waste disposal

Land use

Availability of state and local news

Street improvement and construction including

sidewalks and walkways

Parks and recreation

Industrial-business base

Child care

Sewers

Juventle services

Schools and education

Community spirit and involvement

Housing needs

Health services including both medical and dental

Employment and job training

Services for the handicapped

(Read top to bottom--bottom to top every other time.) 
Card given to respondent:

1. Very important

2. Of some importance

3. Not important

24. Are you registered to vote? Yes

No

IF YES TO QUESTION 24--

25. Have you voted within the last year?

2 years?

3 years?

4 years?

IF NO TO QUESTION 24--

26. Are you eligible to register? Yes

No

Don't know

27. Are you affiliated with a political party? Yes

No

Unsure

23. Have you actively campaigned for any candidate within the past 4 years? Yes

No

IF YES TO QUESTION 28--

29. What offices did these candidates run for? 
30. Have you helped circulate any initiatives or petitions within the past 2 years? Yes

No

31. Have you attended any governmental public meetings within the last year? (Such as county hearings, school board meetings, county commission meetings, etc.) Yes No

IF YES TO QUESTION 31--

32. What kind of meetings did you attend?

33. Did you attend. . less than 3 meetings?

3-10 meetings?

11-20 meetings?

more than 20 meetings?

34. To what community or service organizations other than ECO do you now belong, if any? 
I MARRIED--

35. Does your husband/wife belong to ECO? Yes

No

36. To what community or service organizations (other than ECO) does he/she now belong, if any?

37. How long have you been active in community and service organizations as an adult? Less than 1 year

1 to 3 years

3 to 6 years

6 years or more

38. Did you belong to CUE (Citizens United for Evergreen) last school year?

Yes

No

Don't know

39. Do you see yourself as having been very active, moderately active, or not very active in ECO? Very active

Moderately active Not very active 
40. Which ECO committee did you belong to last spring, if any? Boundary

Communication

Questionnaire

None

41. Were you an officer of any kind in ECO last spring?

Yes

No

42. Why did you decide to participate in ECO?

43. About how many people in ECO did you know before you joined the group? Less than $10 \%$

$10 \%$

$25 \%$

$50 \%$

$75 \%$

Almost all 
44. Have any of your friends jolned the group at your suggestion? Yes

No

45. The number of people attending ECO has decreased since the first two meetings. What is it that kept you coming last spring instead of dropping out as many others did?

46. At the time that you joined ECO did you think that you might be able to learn new things by particlpating in the group? Yes

$$
\text { No }
$$

Don't know

IF YES TO QUESTION 46--

47. What did you hope to learn? 
48. Do you feel that participation in ECO can be helpful to you in your job or career? Yes

No

Don't know

IF YES TO QUESTION 48--

49. How?

50. As you work with ECO, do you feel that your ideas are I1stened to and taken into account by the group? Yes

No

Don't know

51. How much do you feel that you are able to influence what happens in ECO?

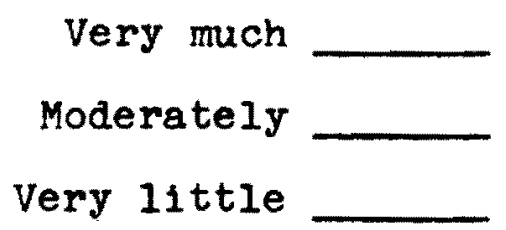

52. Are you satisfied with the decision making process which occurs at ECO?

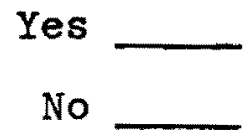

Don't know 
IF NO TO QUESTION 52--

53. Why not?

54. If you had to declde what issues or projects ECO should work on, which would you place first; second, and third?

1.

2.

3.

55. How well do you think that the University of Washington consultants are serving ECO? Very well Fairly well Okay

Pairly poorly Very poorly No opinion 
56. Should ECO receive more, less, or about the same kind of degree of guidance from the consultants? More

Less

Same

No opinion

IF MORE IN QUESTION 56--

57. What form should this assistance take?

IF LESS IN QUESTION $56--$

58. In what areas should the consultants de-emphasize their role? 
59. (Give respondent card) on this card are a number of statements which describe some of the possible ways which other people might react to your participation in ECO. Would you please read them and then tell me which sentence best describes the way that your friends or neighbors view your participation?

IF EMPLOYED--

How about the people where you work? And your family?

Card given to respondent:

1. They encourage my community involvement in general.

2. They are especially interested in my work with this particular group.

3. They neither encourage nor discourage my activities.

4. They are unaware of my participation.

5. They discourage my activities.

6. They are critical of my association with this group. 7. They have not expressed any feelings. 
60. Does your family seem to resent the time and energy which are required by your participation in ECO?

Very definitely
Yes somewhat
Unsure
No
Absolutely not

61. Which of the following statements do you think best describes how local government officials view ECO? (Circle answer number)

1. They are unaware of ECO.

2. They have a "wait-and-see" attitude.

3. They are hopeful that ECO will achieve its goals. 4. They are eager to assist ECO in any way. 5. No opinion.

62. Do you have any other comments you'd like to make concerning the kinds of things we've been discussing? 


\section{APPENDIX II \\ INTRODUCTORY IETTER TO RESPONDENTS}

October 8,1975

Dear Fellow ECO Member:

The purpose of this letter is to enlist your cooperation in a research project which we have undertaken as part of our Master's Degree program in the School of Social Work at Portland State University. We are making a study of ECO members related to their participation in ECO last spring. You have been selected as a member of the group under study. We will contact you by phone to arrange a convenient time for a half hour interview to take place beginning october 13 th.

We would appreciate your cooperation in this research project, and you may be assured that your responses will be completely confidential--the data will be compiled without use of the names of respondents. We look forward to interviewing you next week, and we will be contacting you soon. Thank you for your assistance.

Sincerely,

Doug Lehrman

Jan Abrams 


\section{APPENDIX III \\ POLLOW-UP LETTER TO RESPONDENTS}

November 13,1975

Dear

Thank you for allowing us to interview you recently regarding your participation in the Evergreen Community Organization (ECO). We appreciate your having taken the time to talk with us and to help us with our research. We are presently compiling and analyzing the data received from the interviews. We will present the results of our study sometime this winter, probably at an ECO meeting, in case you are interested in knowing what we learn about the members of ECO as a group. (Individual replies to questions will be confidential--the data will be analyzed for the group as a whole.)

Again, thank you for your time and assistance in our research project.

Sincerely,

Jan Abrams

Doug Lehrman 